\title{
Genesis and rank distribution of Upper Carboniferous coal basins in the Cantabrian Mountains, Northern Spain
}

\author{
Juan Ramón Colmenero a, Isabel Suárez-Ruiz ${ }^{\mathrm{b}, *}$, Javier Fernández-Suárez ${ }^{\mathrm{c}}$, Pedro Barba ${ }^{\mathrm{a}}$, Teresa Llorens ${ }^{\mathrm{a}}$ \\ a Department of Geology, Salamanca University, 37008-Salamanca, Spain \\ b Instituto Nacional del Carbón (INCAR-CSIC). Ap. Co, 73. 33080-Oviedo, Spain \\ c Department of Petrology and Geochemistry, Complutense University, 28040-Madrid, Spain
}

A B S T R A C T

The Cantabrian Mountains located in the NW of the Iberian Peninsula constitute the most important coal-mining district of Spain. Anthracitic and bituminous coals (high and medium rank coals) have been mined in the area since the end of the nineteenth century and they currently account for about 70\% of the total coal resources of the country. The region forms part of the Cantabrian and West Asturian-Leonese Zones of the Iberian Variscan Fold Belt and is strongly deformed by a set of imbricate thrusts, coeval folds and high-angle faults. Coal-bearing successions are Westphalian and Stephanian (Pennsylvanian) in age and are exposed in numerous coalfields of variable size arranged roughly parallel to the tectonic structures.

Coal rank varies from medium-rank bituminous $\mathrm{D}$ coals $(\mathrm{Rr} \geq 0.5 \%)$ to high-rank anthracites

A coals $(\mathrm{Rr}<6.0 \%)$. The regional rank distribution can be correlated with the increase in the thermal effect observed from Westphalian to the Stephanian coals, and from the Cantabrian Zone to the West Asturian-Leonese Zone. These rank variations are related to the thermal processes caused by the emplacement of some major faults, and granitoids and mafic rocks in upper crustal levels and the subsequent development of the regional methamorphic contact aureoles.

\section{Introduction}

The Cantabrian Mountains are an E-W trending range located in Northern Spain. They comprise a Variscan basement of Precambrian and Paleozoic age belonging to the Cantabrian and West AsturianLeonese Zones of the Iberian Massif and a Mesozoic and Tertiary cover (Fig. 1). All these materials have subsequently been deformed by the Alpine Orogeny.

Most of the Spanish coal basins are located in the Cantabrian Mountains (Fig. 1). They contain about $70 \%$ of the total coal, and $95 \%$ of the anthracitic and bituminous resources in Spain. Mining in the region has been taking place since the end of the 18th century. Today, this activity is in deep crisis due to the depletion of resources and the difficulties in coal extraction, together with the environmental problems nowadays associated with mining.

Coal-bearing successions in the Cantabrian Mountains are Late Carboniferous (Pennsylvanian) in age and their deposition took place in an orogenic context during the Variscan activity (380-280 m.y.). The ages of the coal deposits vary from late Upper Namurian to Stephanian B and C (Fig. 1). In order to describe these successions and taking into account a combination of features such as ages, tectonic

\footnotetext{
* Corresponding author. Tel.: +34 985119090; fax: +34 985297662.

E-mail addresses: colme@usal.es (J.R. Colmenero), isruiz@incar.csic.es (I. Suárez-Ruiz),jfsuarez@geo.ucm.es (J. Fernández-Suárez).
}

setting and depositional processes, the successions have been grouped into Upper Namurian-Westphalian, Cantabrian-Barruelian and Stephanian B-C coal-bearing series (Fig. 1).

The Upper Namurian-Westphalian successions occupy a wide geographic domain of approximately $1500 \mathrm{~km}^{2}$ in the central part of the Cantabrian Zone composed from W to E, of relevant coalfields such as Teverga, San Emiliano, Quirós, Central Asturian and La MareaCoballes. All these coalfields are separated from one another by major thrust units. The Cantabrian-Barruelian coal-bearing successions occur in the SE of the Cantabrian Zone, where they form the Guardo, La Pernía, Castillería, Redondo and Barruelo coalfields (Fig. 1). Other successions with similar ages are located towards the north of the region such as Sebarga-Fontecha and Gamonedo-Cabrales coalfields but the economic importance of their coals is negligible. The Stephanian B and C successions are widespread in the Cantabrian Mountains, unconformably overlying basement units ranging from Precambrian to Carboniferous age. They form isolated and small coalfields arranged more or less parallel to tectonic structures in the Cantabrian Zone (Canseco-Salamón, Sabero and Ciñera-Matallana coalfields), Narcea Antiform (La Magdalena, Villablino, Rengos, Carballo, Cangas and Tineo coalfields) and West Asturian-Leonese Zones (El Bierzo coalfield). El Bierzo coalfield is subdivided from the mining perspective in three sectors: Torre-Bembibre, Fabero-Matarrosa and Toreno-Valdesamario.

The main geological features of the Cantabrian Mountains and the associated coal basins have been described in numerous publications 


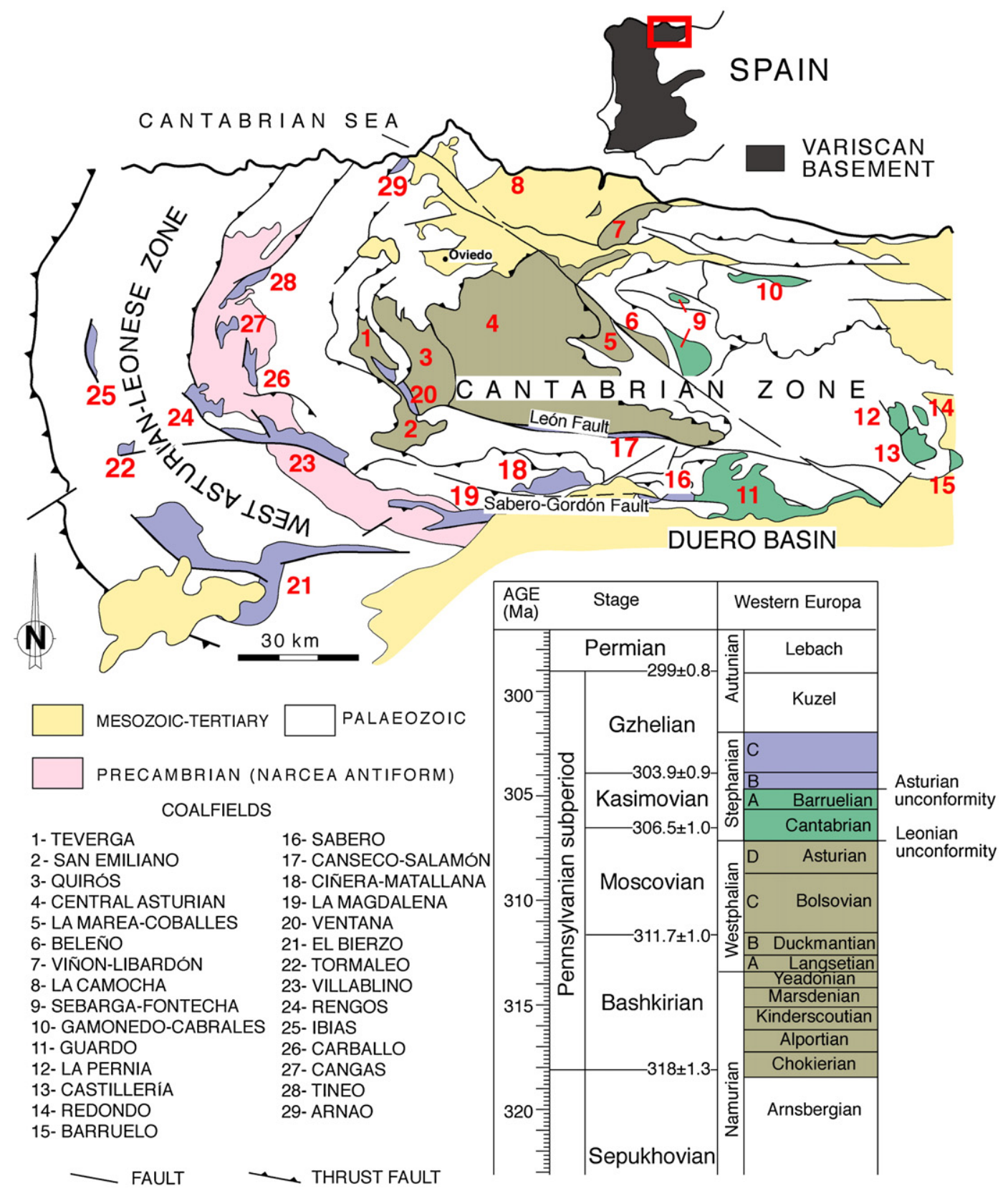

Fig. 1. Schematic geological map of the Cantabrian Mountains showing the location of the most important Carboniferous coalfields.

and 1:50,000 geological maps edited by the Spanish Geological Survey (IGME). General reference works can be found in Dallmeyer and Martínez García (1990), Gibbons and Moreno (2002), and Vera (2004).

In relation to the petrology of the Carboniferous coals, few studies have been published. Colmenero and Prado (1993) were the first authors to publish a map of ranks of the area based on the volatile content of the coal. They discuss the possible causes of the coal-rank variability on a regional scale. Piedad-Sánchez (2004), and PiedadSánchez et al. (2004a,b) studied the petrography, chemical composition and thermal evolution of coals in the Central Asturian coalfield (Westphalian age), while Frings et al. (2004) carried out a similar study in the Ciñera-Matallana basin (Stephanian age).

In this work we approach the study of coal basins of the Cantabrian Mountains through three main steps: i) - a description of the general geological features of the coal basins, ii) - a description of the coal petrology including the maceral composition of coals and the analysis of the rank distribution within the different coal basins through sketch maps, and iii) - a discussion of the factors controlling coal rank and its variation on a regional scale.

\section{Regional framework}

The coal basins of the Cantabrian Mountains form part of the Cantabrian and West Asturian-Leonese Zones of the Iberian Massif which constitutes the westernmost exposure of the European branch of the Variscan Orogen produced by continental collision between Gondwana and Laurassia (e.g. Martínez-Catalán et al., 1997; Matte, 2001). The Iberian Massif shows an arcuate shape pattern known as Asturian or Ibero-Armorican Arc acquired during Late Carboniferous times coeval with the last Variscan movements (Pérez-Estaún et al., 1988; Gutiérrez-Alonso et al., 2004).

The Cantabrian Zone (Figs. 1 and 2) is exposed in the core of the Asturian arc and represents the foreland thrust and fold belt in the north of the Iberian Massif. It is formed by Palaeozoic sedimentary 


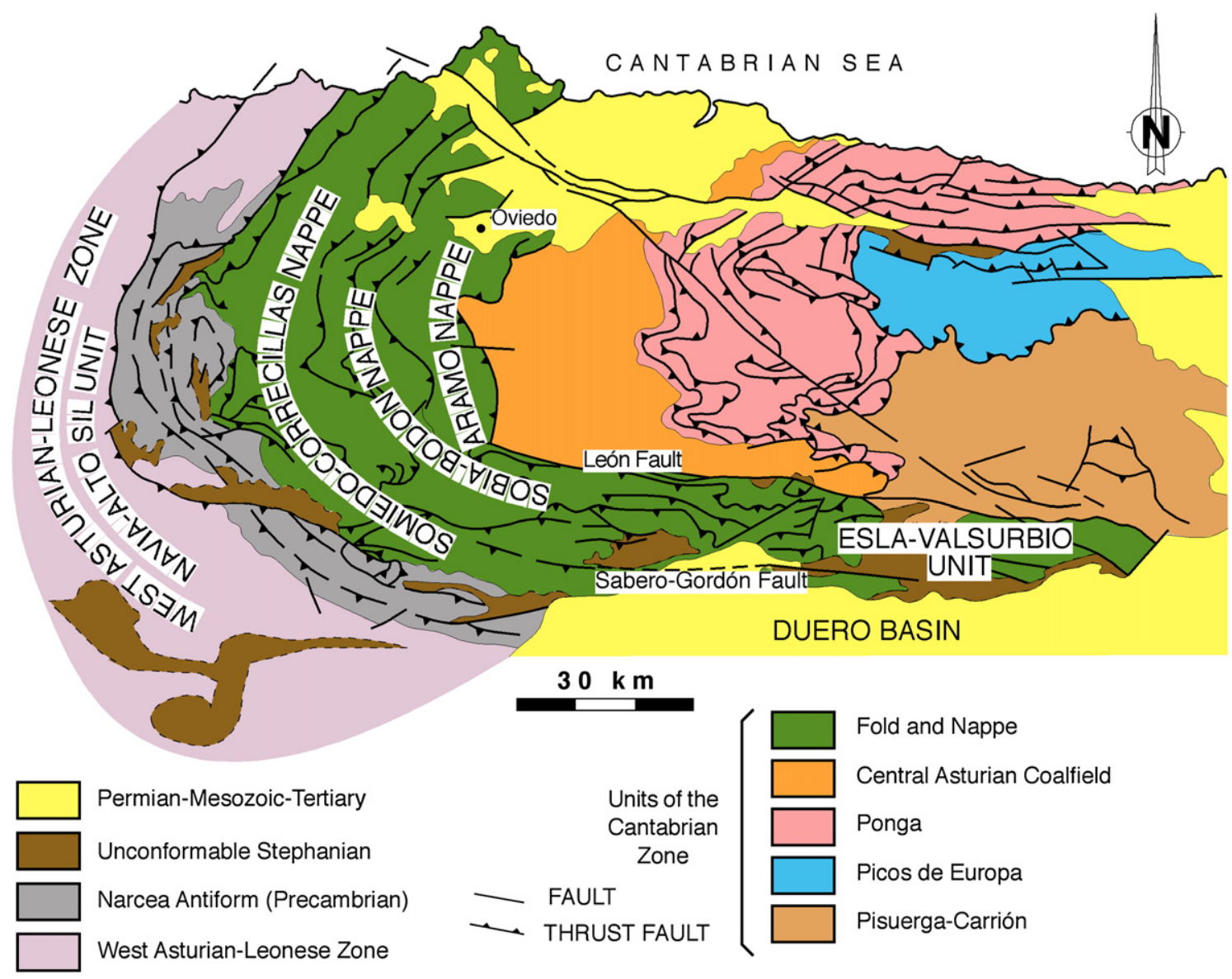

Fig. 2. Geological sketch map of the Cantabrian Zone showing the tectonostratigraphic provinces and tectonic units (based on Julivert, 1971; Pérez-Estaún et al., 1988).

rocks, mostly Devonian and Carboniferous in age, deformed by imbricate nappes and thrusts directed toward the core of the Arc. Julivert (1971) and Pérez-Estaún et al. (1988) divided the Cantabrian Zone into five tectonostratigraphic units, named, from the most internal to the most external parts: Fold and Nappe Unit (which comprises the Somiedo-Correcillas, Sobia-Bodón, Aramo and EslaValsurbio nappes), the Central Asturian Coalfield, Ponga Nappe, Picos de Europa and Pisuerga-Carrión Units (Fig. 2). Magmatism and metamorphism in the Cantabrian Zone are volumetrically scarce in comparison with other zones of the Iberian Massif. Magmatism resulted in small granite stocks, dykes and sills emplaced at the Carboniferous-Permian boundary in extensive late-Variscan structures in the Nappe and Folds, Ponga Nappe and Pisuerga-Carrión domains (where almost 250 granite stocks have been identified by Corretgé and Suárez, 1990). The metamorphic grade is low to very low in all these units (Aller et al., 2004).

García-Lopez et al. (1999) have suggested that only in the western sectors of the Cantabrian Zone is there a manifest Variscan regional metamorphism, whereas the rest of the Cantabrian Zone metamorphism is either due to the contact effect of intrusions or is a very lowgrade metamorphism resulting from fluid circulation in the vicinity of the major faults.

The West Asturian-Leonese Zone represents a more internal segment than the Cantabrian Zone (Fig. 2) from which it is separated by a complex antiformal structure known as the Narcea Antiform composed of a thick Late Proterozoic succession of shales and volcanic rocks. Marcos (1973) subdivided the West Asturian-Leonese Zone into three domains on the basis of tectonostratigraphy and plutonometamorphism: the Mondoñedo Nappe, Navia-Alto Sil and TruchasCaurel. The stratigraphy of the Navia-Alto Sil domain, where there is only located a single coalfield (El Bierzo coalfield) is represented by very thick (up to $10,000 \mathrm{~m}$ ) siliciclastic Cambrian and Ordovician rocks, deformed by large recumbent folds which are cross-cut by deep-rooted thrusts. Metamorphism is low to medium grade and is distributed in bands parallel to the main structural trend that result from the juxtaposition of thermal highs with associated plutonism (Corretgé et al., 2004).

Variscan compressive movements affected the West AsturianLeonese and Cantabrian Zones during Carboniferous times when a succession of nappes and thrusts occurred in a piggy back or forward sequence. The characteristic arcuate geometry of the region has been explained by Pérez-Estaún et al. (1988) as a more or less progressive process caused by the successive change in the direction of emplacement of the nappes and thrusts during Late Carboniferous times. Most recently, Weil et al. (2000, 2001), Gutiérrez-Alonso et al. (2004), and Weil (2006) have suggested that the oroclinal structure of the Iberian Massif was acquired as a result of the $\mathrm{N}-\mathrm{S}$ convergence between Gondwana and Laurentia at the Carboniferous-Permian boundary. Finally, an extensional collapse phase of the Variscan orogeny took place during the Early Permian time giving rise to continental rift basins associated with volcanism, granitic intrusions and heat flow (López-Gómez et al., 2002). A later extensional phase, related with the opening of the north Atlantic rift and the bay of Biscay followed during the Triassic, Late Jurassic and Early Cretaceous times (Espina et al., 2004; Pujalte et al., 2004; García-Mondejar et al., 2004). Alpine tectonics during the Tertiary period gave rise to the regional reactivation of thrusts and other Variscan structures, the inversion of Mesozoic distensive faults and the formation of new alpine faults. All these changes were associated to $\mathrm{N}-\mathrm{S}$ compression which caused the elevation of the present-day Cantabrian Mountains and their thrust over the Tertiary materials of the Duero Basin (south of the studied area shown in Fig. 1; Alonso et al., 1996; Alonso and Pulgar, 2004). 


\section{Geology of the coal basins}

3.1. General characteristics of the Upper Namurian-Westphalian coal basins

These basins occupy a wide geographic domain of approximately $1500 \mathrm{~km}^{2}$ in the central part of the Cantabrian Zone (Fig. 1) composed, from W to E, of the Teverga, San Emiliano, Quirós, Central Asturian and La Marea-Coballes coalfields and other minor coalfields such as Viñón-Libardón, Beleño and La Camocha. The major coalfields are separated from one another by major thrust units.

The different Namurian-Westphalian coal-bearing successions show similar characteristics. They reach up to several thousands of metres in thickness and are conformably overlying older Namurian rocks. The successions form coarsening and shallowing-upwards mega- sequences in which two intervals can be distinguished. The lower interval is composed of alternating mudstones and limestones with a small amount of sandstones and minor coals (Lena Group, Fig. 3). The upper interval is formed by cyclic alternations of mudstones with minor limestones and abundant productive coal seams (Sama Group, Fig. 3). In the Central Asturian coalfield, two thick conglomeratic units (ca. 1,000 m each) occur in the upper part of the succession. The ages of these coalbearing successions become younger eastward, varying from Namurian C-Westphalian A (Teverga-San Emiliano coafield), Westphalian B-D (Central Asturian coalfield) and Westphalian D (La Marea-Coballes coalfield).
Sedimentation of coal-bearing facies in these coalfields took place in deltaic, fan-delta and other coastal paralic sedimentary environments (Fernández et al., 1988; Águeda et al., 1991; Colmenero et al., 1993; among others) (Fig. 3). Each of them can be considered as structural remnants of a single, strongly asymmetrical, and rapidly subsiding foreland basin which developed ahead of the orogenic front and subsequently underwent progressive shortening as a result of nappe movement (Marcos and Pulgar, 1982; Fernández et al., 1988; Águeda et al., 1991; Colmenero et al., 1993; Colmenero et al., 2002; Fernández et al., 2004).

Coals seams in the Upper Namurian-Westphalian coalfields are relatively extensive and numerous (up to 70 different coal seams have been worked in the Central Asturian coalfield). Piedad-Sánchez (2004) and Piedad-Sánchez et al. (2004a,b) have reported detailed studies of the petrography, geochemistry and thermal history of the workable coal seams from the northern part of the Central Asturian coalfield.

\subsection{General characteristics of the Cantabrian-Barruelian coal basins}

The coal-bearing successions included in this group are exposed towards the E and SE of the Cantabrian Zone, in the central part of the Asturian Arc (Fig. 1). Whereas some of them (e.g. Sebarga-Fontecha and Gamonedo-Cabrales coalfields, Fig. 1, within the Ponga Nappe Unit) contain negligible coal resources, all the other successions have been mined from early times until the present day. They are unconformably overlying older sediments of the Esla-Valsurvio

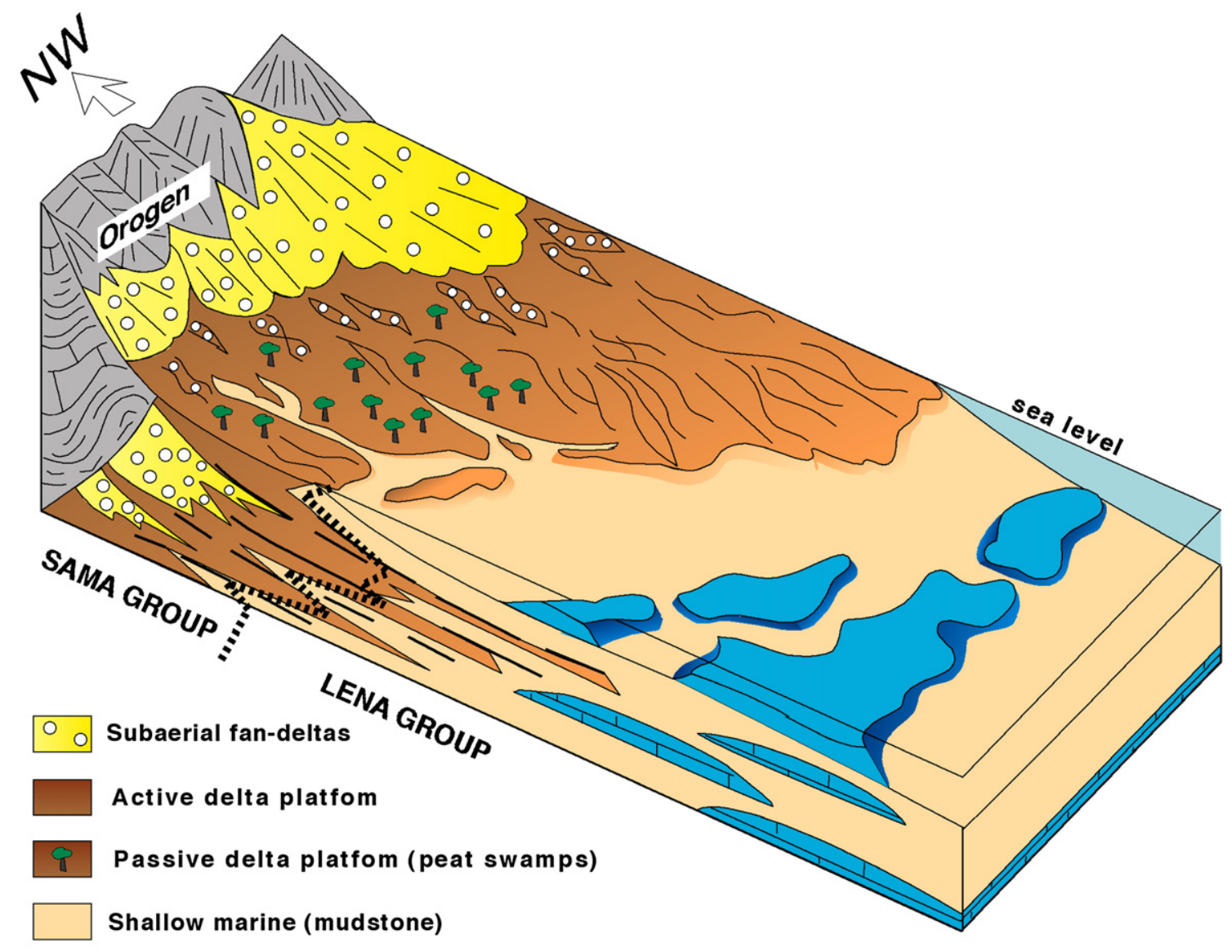

Bioclastic and algal-bound limestones

Coal seams

Fig. 3. Block diagram showing an idealized model of the Namurian-Westphalian depositional environments (modified from Agueda et al., 1991). 
(Guardo coalfield) and Pisuerga-Carrión unit that form the La Pernía, Castillería, Redondo and Barruelo synclines (locations are shown in Fig. 1). The basal unconformity has been named "Leonian" by Wagner (1959) and its age is Upper Westphalian D. Towards the top it is separated from the Stephanian B-C sequences by an unconformity named "Asturian" unconformity (Wagner, 1959). The age of the coalbearing successions varies from basin to basin. The ages of the coalbearing facies vary from Upper Westphalian D-Lower Cantabrian in the Guardo and La Pernía coalfields to Lower Barruelian in the Redondo and Barruelo coalfields (Wagner and Winkler Prins, 1985). All the successions have a significant chronostratigraphic value as they have been used to establish the stratotypes of the Cantabrian and Barruelian stages (Wagner and Winkler Prins, 1985). The main features of these basins are summarised below:

The Guardo coalfield (Fig. 1) occurs along an E-W oriented band approximately $45 \mathrm{~km}$ long and its sequences are unconformably overlying Palaeozoic rocks of the Esla-Valsurvio domains of the Folds and Nappes Unit (Fig. 2). The deposits belong to the so called Cea Group and are intensely folded and faulted. The Guardo basin has been sub-divided in three sectors: Guardo-Cervera, Valderrueda and Ocejo-Tejerina (see Fig. 1 and those of coal rank distribution). In the eastern Guardo-Cervera sector, the successions reach $1500 \mathrm{~m}$ in thickness and are Upper Westphalian D-Lower Cantabrian in age. They form an asymmetric syncline crosscut by a large number of major faults striking roughly parallel to the outcrop. In the intermediate Valderrueda sector, the successions are mainly Lower Cantabrian in age and develop a complex synclinoidal structure reaching up to $3500 \mathrm{~m}$ in thickness. The westernmost Ocejo-Tejerina sector, of Lower Cantabrian and early Upper Cantabrian age, the successions infill and overlie a buried topography cut into the Devonian and Carboniferous series of the Esla Nappe (Iwaniw, 1983, 1984; Alonso, 1985; Llorens et al., 2006a; see Fig. 2). There are about 50 coal seams in the central and eastern part of the basin, of which 12 are still being mined. In the western sector only 3 seams have been mined.

In La Pernía syncline (Fig. 1) the coal-bearig successions are Upper Westphalian D in age whereas in the Castillería syncline they are
Upper-Westphalian D and Lower Cantabrian (Wagner and Winkler Prins, 1985). In both synclines, the coal bearing units have a thickness of a few hundred metres and overly calcareous or siliciclastic units deposited in a deep platform environment. As for the coal seams, 15 seams (all thin and of short lateral continuity) have been mined.

The Redondo and Barruelo coalfields (Figs. 1 and 4) form synclinal structures, whose normal limb has been truncated by the RedondoBarruelo thrust. In both, the coal-bearing sequences belong to the Barruelo Formation, of Lower Barruelian age (Wagner and Winkler Prins, 1985). In the Barruelo syncline, the succession has a thickness of up to $1200 \mathrm{~m}$ and includes 12 coal seams. In the Redondo synform, the Barruelo Formation reaches a thickness of about $900 \mathrm{~m}$ and contains 5 coal seams whose thickness ranges from 0.5 to $1.5 \mathrm{~m}$ (Bahamonde and Nuño, 1991).

Most of the coal-bearing sequences in these coalfields consist of interbedded sandstones and lutites (sometimes interbedded with quarzitic and calcareous conglomerates) forming shallowing-upwards cycles of fan-deltaic and deltaic origin (van de Graaff, 1971; Alonso, 1985; Bahamonde and Nuño, 1991; Saldaña González, 1994). The origin of these basins has been a matter of debate. Wagner and Varker (1972), and Wagner and Winkler Prins (1985) suggested that all the coalfields were initially part of a single extensional basin controlled by normal faults that extended progressively westwards and eastwards from the present-day Casavegas region. An alternative hypothesis presented by Heward (1978a,b), Heward and Reading (1980), and Nijman and Savage (1989) suggests that these basins are remnants of the infill of an E-W trending pull-apart basin generated by the motion of the Leon and Sabero-Gordón faults (Fig. 1) at the Westphalian DStephanian boundary. More recently, Bahamonde and Nuño (1991) suggested that the Redondo coalfield is the result of the infill of a foreland trough associated with thrust emplacement. Colmenero et al. (2002) interpreted the La Pernía, Barruelo and Redondo basins in the same way. They consider that these sequences are remnants of a major foreland basin that occupied the Pisuerga-Carrión domain during Cantabrian and Barruelian times that were uplifted during the eastward emplacement of the Ponga and associated Valdeón, Fuentes Carrionas, La Pernía and Barruelo nappes (Fig. 4).

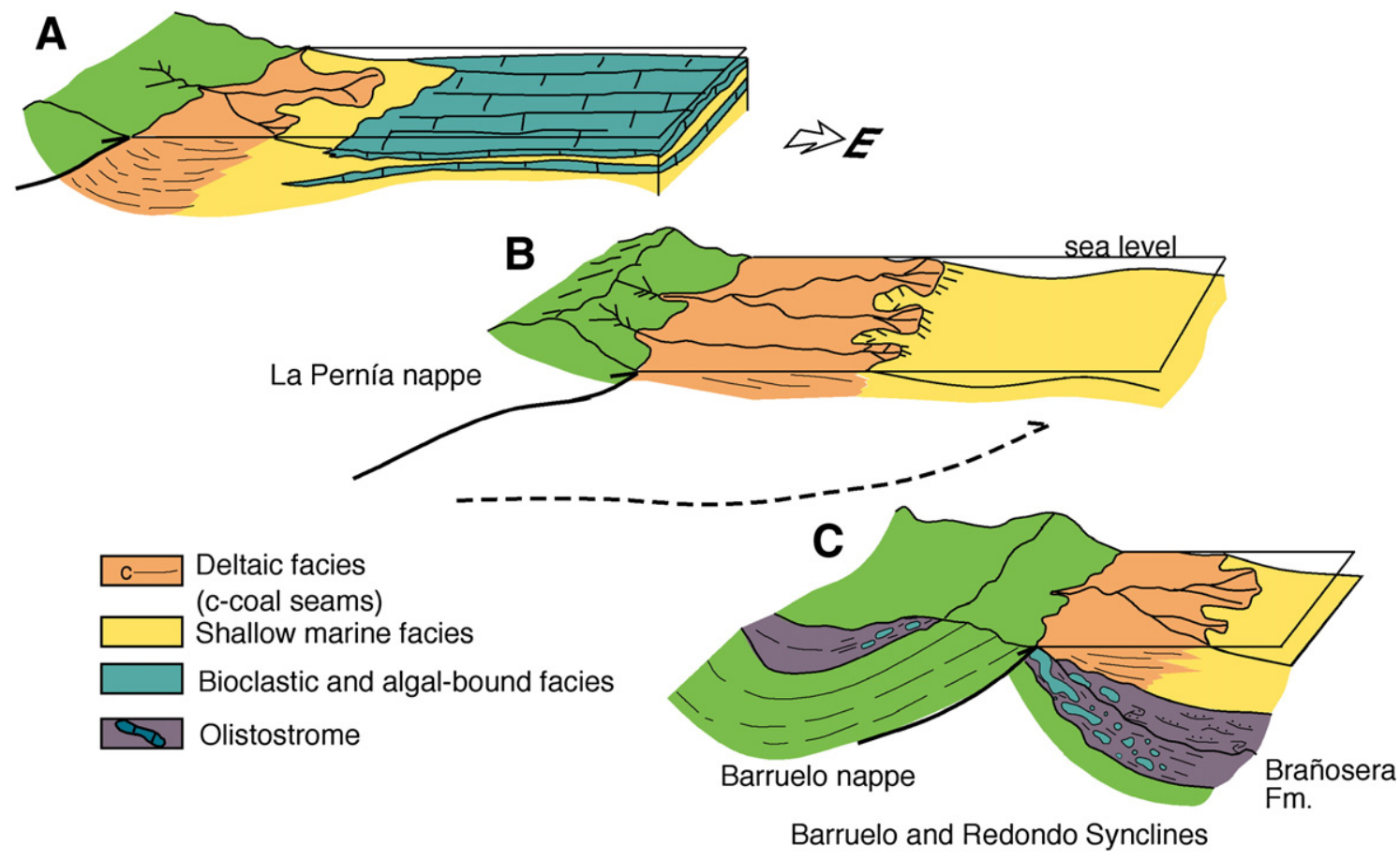

Fig. 4. Schematic sketches of the tectosedimentary structures of the Cantabrian-Barruelian coalfields. 


\subsection{General characteristics of the Stephanian $B$ and $C$ coal basins}

The Stephanian B and C coal-bearing successions are widespread in the Cantabrian Mountains (Figs. 1 and 2) resting unconformably on Carboniferous to Precambrian strata of the Cantabrian Zone (Sabero, Ciñera-Matallana, Canseco-Salamón and Ventana coalfields), Narcea Antiform (La Magdalena, Villablino, Rengos, Carballo, Cangas and Tineo coalfields), and the Navia-Alto Sil unit of the West Asturian-Leonese area (El Bierzo coalfield). These successions crop out in a series of synclines of variable size arranged more or less parallel to the basement of the Variscan structures. They are strongly folded and faulted and, in general, show one relatively undeformed and well preserved flank whereas the other has been extensively disturbed by late-Variscan faults reactivated during the Alpine orogeny (Fig. 5A). The ages of these successions, established by flora studies, become younger westward and vary from Barruelian-Stephanian B (Sabero coalfield) to Stephanian B-C (Villablino, Rengos, Carballo, Cangas, Tineo and El Bierzo coalfields). Sills and dykes of mafic rocks are found in all these basins either crosscutting the coal-bearing successions or intercalated within them. The main features of these basins are discussed below:

The Sabero is the westernmost coalfield of this group (Fig. 1) and is unconformably overlying the older Paleozoic rocks of the Esla Nappe (Fig. 2). Towards its easternmost part it overlies the Cantabrian age successions of the westhern sector of the Guardo basin (Asturian unconformity). This coalfield defines a tight synclinal E-W trend parallel to the Sabero-Gordón fault (Fig. 2) and is strongly faulted on its southern limb with a length of $17 \mathrm{~km}$ and a maximum width of $3 \mathrm{~km}$. The deposits reach a maximum thickness of $2500 \mathrm{~m}$ and their age is Upper

A

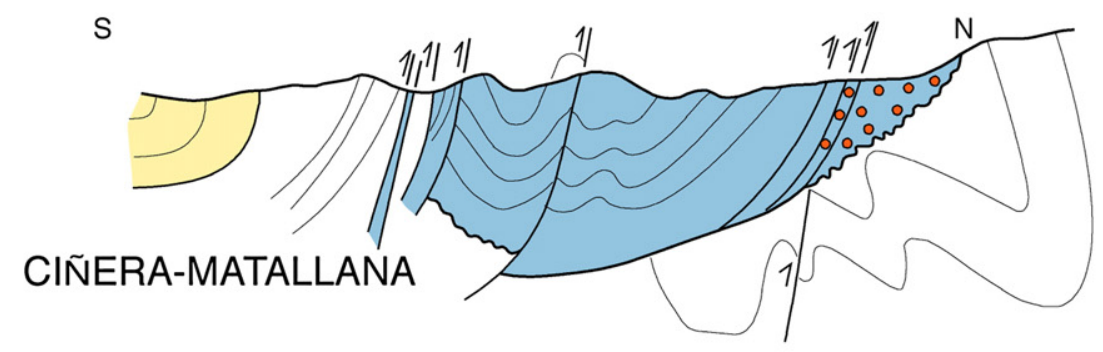

SSO
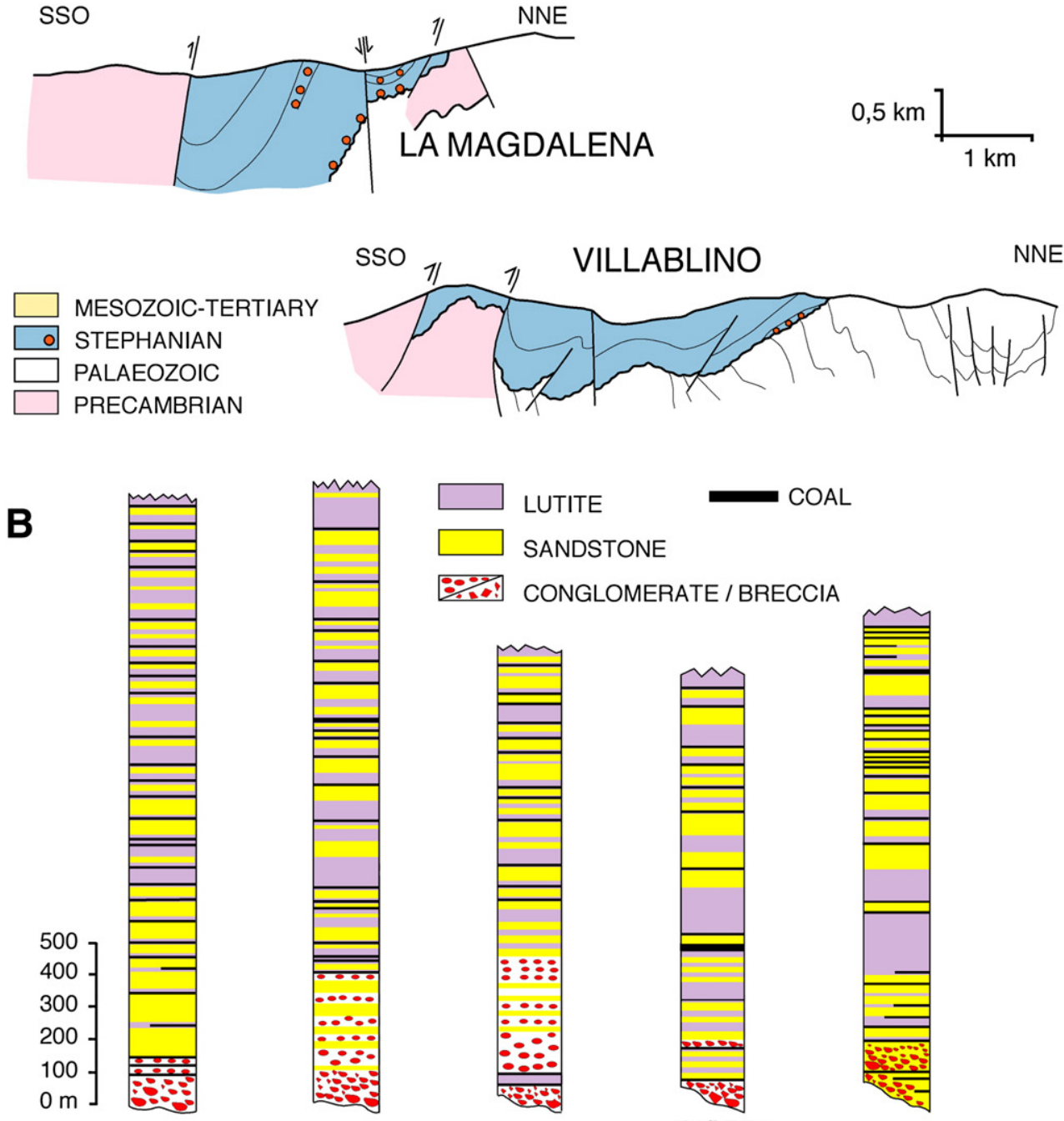

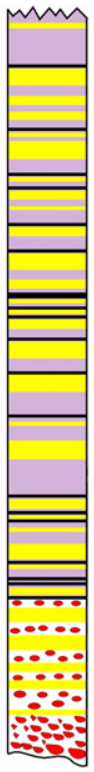

EL BIERZO

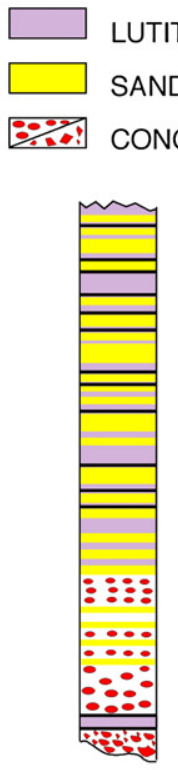

LA MAGDALENA

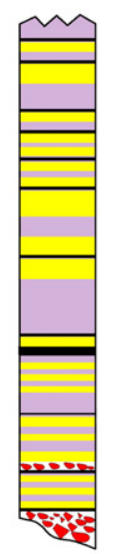

CIÑERA-

MATALLANA
COAL

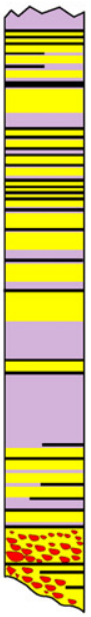

SABERO

Fig. 5. A) Structural cross-sections of three Stephanian B-C coalfields. B) Synthetic stratigraphic column of the Stephanian B-C coal basins. Refer to Fig. 1 for locations. 
Barruelian-Stephanian B (Knight, 1971; Heward, 1978a,b; Knight et al., 1983; Wagner and Winkler Prins, 1985). There are 30 coal seams mostly within the middle and upper part of the succession (Fig. 5B).

The Ciñera-Matallana coalfield (Figs. 1 and 5A) constitutes an E-W trending synclinorium approximately $15 \mathrm{~km}$ in length and $5 \mathrm{~km}$ in width unconformably overlying the Palaeozoic rocks of the Folds and Nappes Unit of the Cantabrian Zone (Fig. 2). The structure is truncated along its length by faults belonging to the Sabero-Gordón lineament (Alonso, 1989). The deposits reach a thickness of $1500 \mathrm{~m}$ and their age is Stephanian B (Wagner and Artieda, 1970; Wagner, 1971). This is one of the most productive coalfields of the Cantabrian Mountains and includes 30 coal seams, one of them, the Pastora seam is up to $20 \mathrm{~m}$ in thickness (Fig. 5B). The coalification history of these coals has been described by Frings et al. (2004).

The Canseco-Salamón and Ventana coalfields are located in the Cantabrian Zone, along the Leon Fault (Fig. 1). The successions of these basins are Lower Stephanian B in age. They show a monoclinal subvertical structure and are unconformably overlying the Westphalian series of the southern margin of the Central Asturian coalfield. Coal seams are scarce and of very limited lateral continuity.

The La Magdalena coalfield (Figs. 1 and 5A) unconformably overlies the Narcea Antiform and the Somiedo-Correcillas Unit of the Cantabrian Zone (Fig. 2). It forms an E-W trending, strongly faulted tight syncline whose southern limb has been almost entirely eliminated by an inverse fault (Fig. 5A). The thickness of the succession is about $1400 \mathrm{~m}$ and its age is Stephanian B (Heward, 1978a). Up to 16 coal seams have been mined.

The Villablino basin (Fig. 1) is located mostly over the Precambrian rocks of the Narcea Antiform (Fig. 2). It is a NW-SE trending syncline faulted and cut by a thrust on its southern limb. The succession is of Stephanian B-C age and has a maximum thickness of $3000 \mathrm{~m}$ (Corrales, 1971) and includes 25-30 coal seams (Fig. 5A,B).

The El Bierzo is the westernmost and largest Stephanian coalfield in the Cantabrian Mountains (Fig. 1). It is unconformably overlying the Lower Palaeozoic rocks of the Navia-Alto Sil Unit of the West Asturian-Leonese Zone (Fig. 2). Structurally it is defined by E-W trending open folds cut by faults that also cut through the older Palaeozoic substratum (Pérez-Estaún, 1978; Fernández García et al., 1984). The coalfield has been subdivided into three sectors mentioned above: Fabero-Matarrosa, Torre-Bembibre and Toreno-Valdesamario. The age of the succession is Stephanian B-C and its thickness reaches 3000-3500 m. About 70 coal seams have been mined in the different sectors (Fig. 5B).

Finally, the Tormaleo, Ibias, Rengos, Carballo, Tineo, Cangas and Arnao coalfields constitute a group of disperse exposures in the West Asturian-Leonese Zone, Narcea Antiform and Cantabrian Zone, whose age is Stephanian B-C (Figs. 1 and 2). They are all of limited extent. The thickness of their successions ranges from $1500 \mathrm{~m}$ (Rengos) and $200 \mathrm{~m}$ (Cangas). About 15 coal seams have been mined in the past in these basins.

All the successions of this group show similar stratigraphic and sedimentological characteristics. They form a large-scale finingupward sequence composed of three parts (Fig. 5B). The lower part displays palaeoreliefs cut into the basement and is composed of laterally discontinuous breccias and pebble-boulder polymodal conglomerates with clasts derived from the immediately underlying rocks. The middle part is formed by conglomerates interbedded with lithic sandstones, mudstones and occasional coal seams. The upper

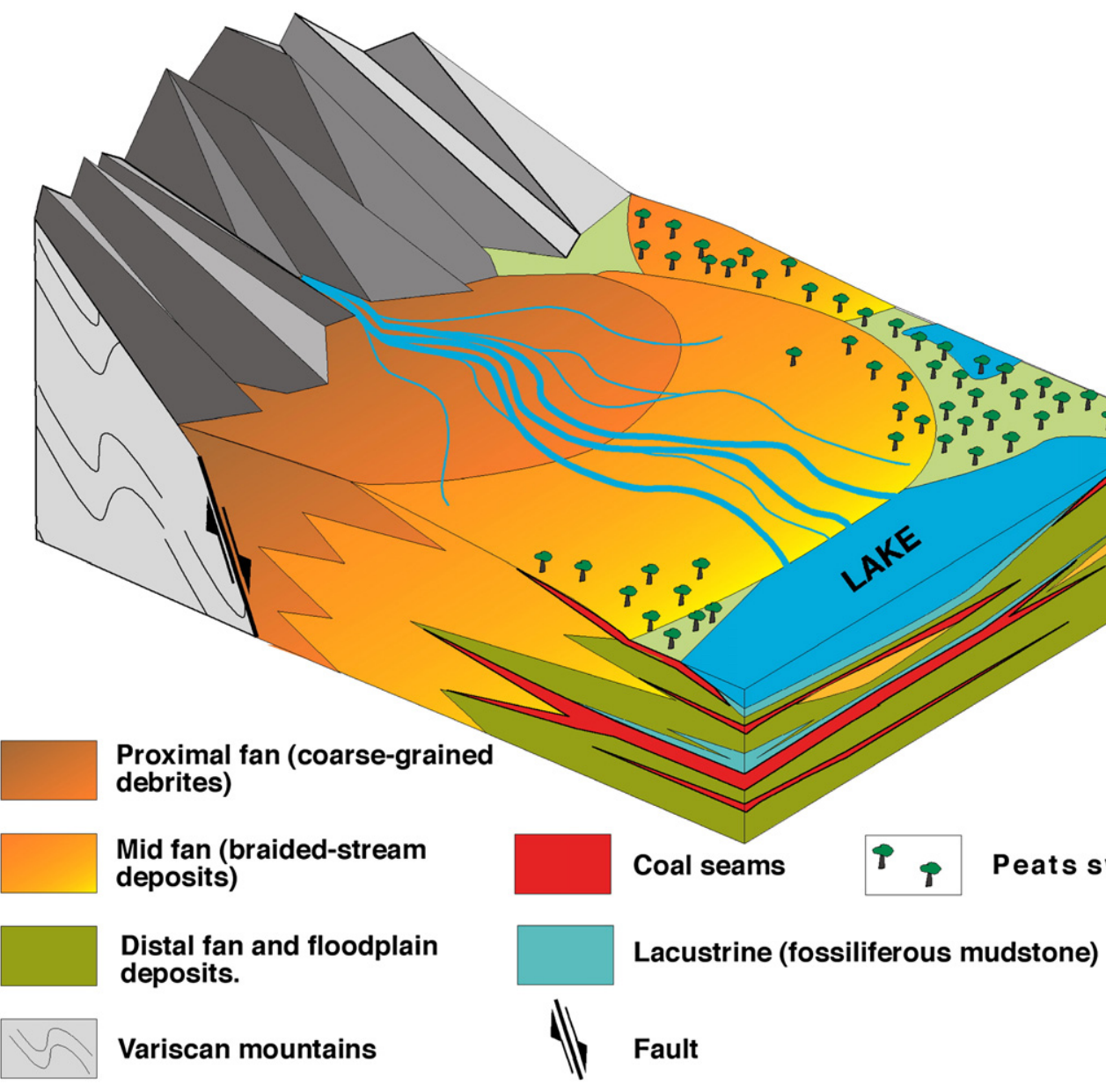

Fig. 6. Schematic alluvial fan-lake depositional model applied to the Stephanian B-C coalfields (modified from Fernández, 1995). 
part is mainly composed of a thick alternation of lithic sandstones, siltstones, mudstones (which frequently contain comminuted plant debris and fresh water fossils of lacustrine origin) and coal seams. In the smallest basins (Canseco-Salamón, Cangas, Tineo, etc, see Fig. 1) breccias and conglomerates are the main remnants preserved. Abundant sills and dykes mostly of mafic rocks occur either intercalated or cutting across the sequence (e.g. Méndez-Cecilia, 1985).

The origin of these Stephanian basins has been a matter of debate. Heward (1978a,b), Heward and Reading (1980), and Nijman and Savaje (1989) suggested that these sequences represent remnants of the filling of a major system of pull-apart basins that extended E-W along the southern limit of the Cantabrian Zone between Westphalian and Stephanian C times. The genesis of these basins would have been linked to the strikeslip motion of faults such as the Sabero-Gordón, León (Figs. 1 and 2) and a deduced fault that is thought to have occurred along the southern limit of the present-day Cantabrian Range. Rodriguez Fernández (1993) and Villegas (1996) pointed out that the genesis of these basins is related to the vertical movement of these faults that gave rise to extensional (graben) basins. A detailed structural work by Alonso $(1982,1985,1989)$ has shown that in some of the basins (e.g., Ciñera-Matallana) the deposition of Stephanian coal-bearing successions was synchronous with folding and tectonic re-activation of basement units. Overall, it can be stated that these sequences represent the filling of intramontane basins (graben or semigrabens) with high subsidence rates developed at the margins of strikeslip and normal faults, some of which (e.g., León and Sabero-Gordón faults) had been active in previous compressional episodes.

Deposition in these basins took place in alluvial fan and lacustrine environments (Heward, 1978a,b; Knight et al., 1983; Fernández García et al., 1984; Colmenero et al., 1996). Two types of alluvial fan replaced one another during the infill of these basins: i) - small-radius alluvial fans or colluvial fans (Fig. 6), confined to palaeo-valleys or to the lower part and foot zone of steep escarpments and mountain slopes formed by breccias and poorly-sorted, massive, clast-supported conglomerates. These materials have been deposited by avalanches and debrisflows and were originated from the bedrock erosion of the adjacent topographic reliefs; and ii) - water-laid alluvial fans larger than the former and made up of siliceous and carbonate sediments derived from large and distal source areas and transported predominantly by sheetfloods and fluvial streams. The tropical and humid climate under which both alluvial fan systems formed contributed to the development of peat swamps on the muddy distal fringes of the fans, in interlobe depressions and along lake margins (Heward, 1978a,b; Colmenero et al., 1996).

\section{Coal petrology}

This section focuses on the coal composition and rank distribution of the Upper Carboniferous coalfields in the Cantabrian Mountains. For this purpose petrologic analyses were performed on representative coal samples taken as channel samples from underground and surface mines, and from outcrops. Petrographic analyses related to coal composition and random reflectance measurements were carried out according to the ISO 7404/3 (1994a) and ISO 7404/5 (1994b) standards respectively. Moreover, proximate analyses were performed following the corresponding ISO 589 (1981), ISO 1171 (1997) and ISO 562 (1998) standards for moisture, ash and volatile matter determinations. Most of the coal data of the Westphalian, Cantabrian-Barruelian and Stephanian B-C samples were compiled from coal studies and coal reports performed at the Instituto Nacional del Carbón (INCAR-CSIC, Spain) in the last 30 years and from various mining companies, coal marketers and Spanish power plants. Thus, this work is developed by using petrographical and chemical data from 721 and 623 samples of Stephanian and CantabrianBarruelian, and Westphalian ages respectively (Table 1). In the case of the Westaphalian coals from the Central Asturian coalfield (Fig. 1) vitrinite reflectance and some volatile matter data from 162 samples already described in Piedad-Sánchez et al. (2004b) were used in this
Table 1

Distribution of the studied coals from the Stephanian and Westphalian coalfields in North Spain

\begin{tabular}{|c|c|}
\hline & Number of samples \\
\hline \multicolumn{2}{|l|}{ Stephanian B-C coalfields } \\
\hline Arnao & 3 \\
\hline Tormaleo, Ibias & 5 \\
\hline Villablino & 113 \\
\hline El Bierzo & 171 \\
\hline Ventana, Rengos, Cangas, Carballo, Tineo & 42 \\
\hline La Magadalena & 79 \\
\hline Ciñera-Matallana & 24 \\
\hline Canseco-Salamón & 35 \\
\hline Sabero & 23 \\
\hline \multicolumn{2}{|l|}{ Cantabrian-Barruelian coalfields } \\
\hline Barruelo & 27 \\
\hline Redondo & 9 \\
\hline Castillería & 9 \\
\hline La Pernía & 10 \\
\hline Valderrueda & 53 \\
\hline Guardo-Cervera & 112 \\
\hline Gamonedo-Cabrales & 3 \\
\hline Sebarga-Fontecha & 3 \\
\hline \multicolumn{2}{|l|}{ Westphalian coalfields } \\
\hline La Camocha & 22 \\
\hline Viñón-Libardón & 2 \\
\hline Beleño & 10 \\
\hline La Marea-Coballes & 25 \\
\hline Central Asturian & 464 \\
\hline Quirós & 40 \\
\hline San Emiliano & 32 \\
\hline Teverga & 28 \\
\hline Total & 1344 \\
\hline
\end{tabular}

162 coal samples of the Central Asturian coalfield are from Piedad-Sánchez et al (2004b), and reflectance data from 19 samples for the Ciñera-Matallana coalfield are from Frings et al. (2004). Refer to Fig. 1 for locations.

work. Vitrinite reflectance data from 19 coals from the Ciñera-Matallana coalfield (Stephanian B-C age) previously published by Frings et al. (2004) were also included in this work. The most recent standard for the Classification of Coals, the ISO 11760 (2005), was applied in all cases to classify the coals from the Carboniferous coalfields and to construct the maps of coal rank distribution.

\subsection{Coal composition}

According to the data compiled from the petrographic analysis on Stephanian B-C, Cantabrian-Barruelian and Westphalian coal seams (including data from the Central Asturian coalfield reported by Piedad-Sánchez et al. 2004a), the Carboniferous coals in this region are, in general, vitrinite-rich coals (from moderately high vitrinite to high vitrinite coals, according to the ISO 11760, 2005) with variable percentages of inertinite and low-to-scarce and, at times, zero liptinite maceral content, particularly in the case of high-rank coals. Westphalian coals, specifically those from the Central Asturian coalfield (Fig. 7), show vitrinite contents usually higher than $60 \mathrm{vol} . \%$ whereas inertinite percentages are higher than 10 vol.\% reaching values of $32 \mathrm{vol} . \%$ ( $\mathrm{mmf}$ ) in some particular cases. Liptinite maceral contents vary between 19 vol.\%. A detailed description of the petrographic composition for the Westphalian coals from the northern part of the Central Asturian coalfield was reported by Piedad-Sánchez et al. (2004a,b).

In the case of the Cantabrian-Barruelian basins, of which the Guardo coalfield is the most representative, the vitrinite maceral group also predominates in all the coals with contents higher than 70 vol.\% (Fig. 7). Due to the high degree of evolution reached by most of the coals in these basins as it is discussed below, no vitrinite maceral varieties can be differentiated because at these stages of coal rank the vitrinite macerals have unified almost all of their physico-optical properties. Inertinite contents are low, although exceptionally this group may exhibit 

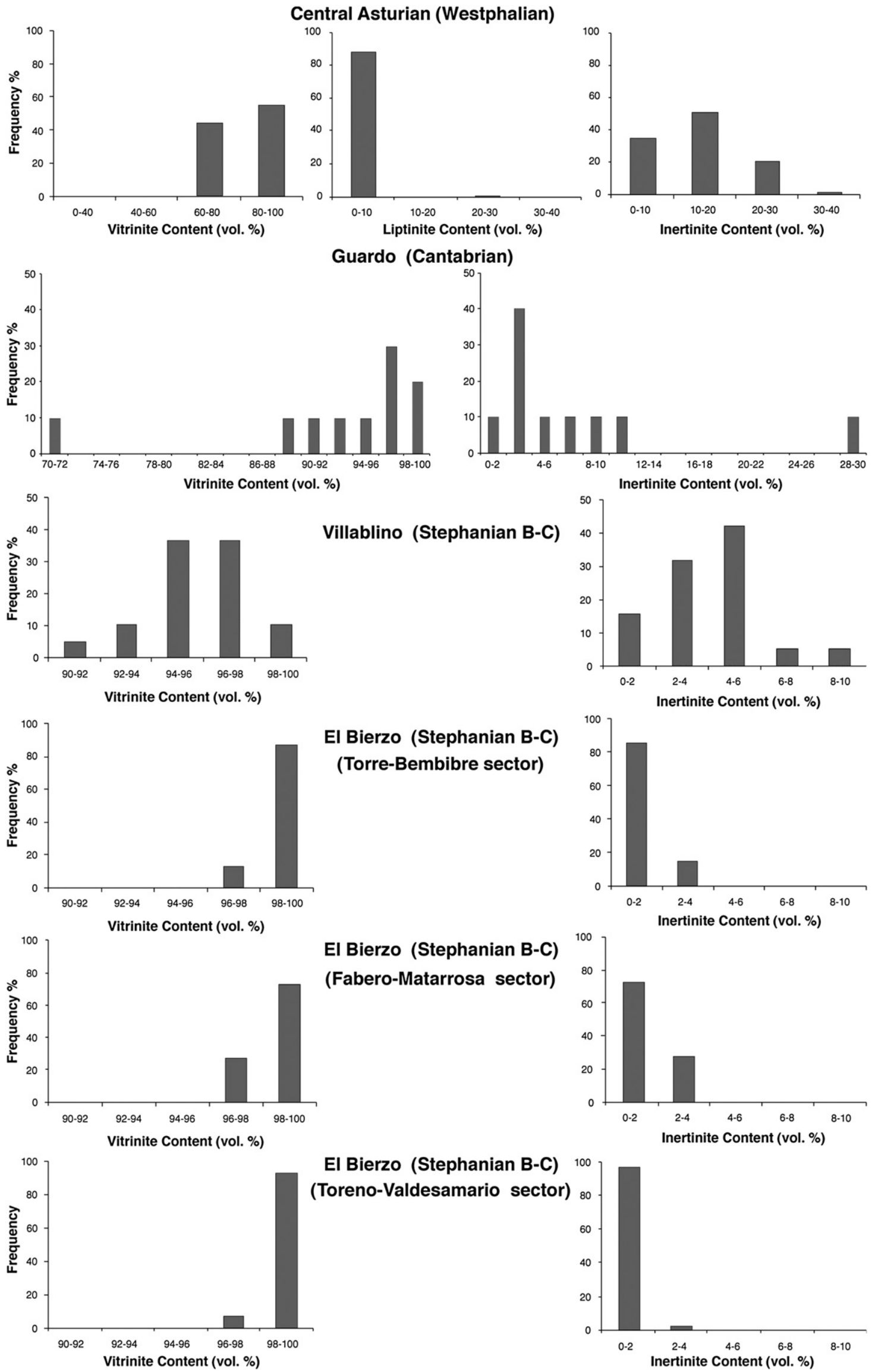

El Bierzo (Stephanian B-C) (Toreno-Valdesamario sector)

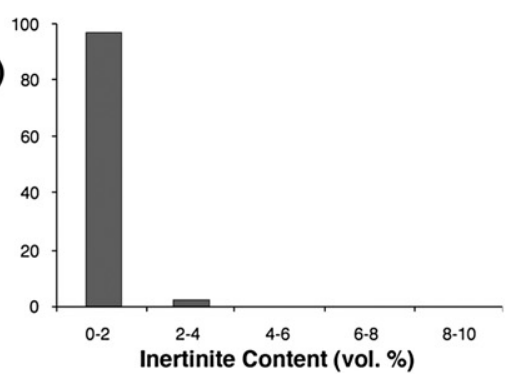

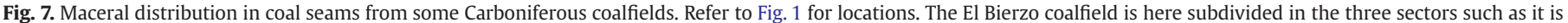
usually known. Data of maceral composition are shown on mineral matter free basis. 
higher percentages ( 29 vol.\%) as in the case of the Esla Mine seams (westernmost part of the Guardo coalfield, Fig. 1).

Coals from the Stephanian B-C age, such as the Villablino and El Bierzo coalfields (Figs. 1 and 7), have a vitrinite content $>80$ vol.\%, reaching in the El Bierzo coalfield values higher than 96 vol.\%. The inertinite maceral content is lower than 10 vol.\% in the case of the Villablino coals, and extremely low ( $<4$ vol.\%) for El Bierzo coal seams. Liptinite macerals are almost non-existent and are only found as traces. Thus, coals from these coalfields can be classified as high vitrinite coals according to ISO 11760 (2005).

The most abundant inertinite macerals in all the Stephanian and most of the Cantabrian-Barruelian coals are semifusinite and fusinite, although some other inertinite macerals such as inertodetrinite, macrinite, etc, can also be found, particularly in the case of the Guardo coal seams. As for the liptinite macerals in Stephanian seams, the significant thermal effect that the coalification process had on these components led to their total transformation with the increase in coal rank as in the case of the most evolved coals. The Stephanian coals of lowest rank also have very few liptinite macerals. The absence of the specific organic raw materials that make up liptinites and the physicochemical conditions of the sedimentary paleoenvironment might also have been factors that influenced the scarce to almost zero liptinite maceral content. Unfortunately this hypothesis cannot be confirmed with the data currently available.

Regarding mineral matter content, Westphalian coals in the studied area have a variable ash content, although coals with very low ash contents ( $<5 \mathrm{wt} . \% \mathrm{db}$ ) are also frequent (Table 2). CantabrianBarruelian and Stephanian B-C coals are characterized by an extremely variable mineral matter content as seen under microscopic examination, which is confirmed by the variations in their ash percentages (Table 2). According to the ash data and following the ISO 11760 (2005) standard, Cantabrian-Barruelian and Stephanian B-C coals have ash yields ranging from low ash (5 to $10 \mathrm{wt} . \%, \mathrm{db}$ ) to high ash contents (30 to $50 \mathrm{wt. \%}, \mathrm{db}$ ). Carbonaceous shales (ash content $>50 \mathrm{wt} . \%, \mathrm{db}$ ) are also very common particularly in the Cantabrian-Barruelian coalfields (Table 2). The different ash contents of the Wesphalian, Cantabrian-Barruelian and Stephanian B-C coal seams are related to the paleoenvironmental conditions and the level of input of inorganic material in the peat swamps. For the CantabrianBarruelian and Stephanian B-C coals no parallel increase in ash and inertinite contents was observed as occurred in the case of some Westphalian age coalfields. Piedad-Sánchez et al. (2004a) attributed this to the fact that in Westphalian age coals particularly in those from the Central Asturian coalfield, the facies have a much more continental than marine character. In all cases the maceral distribution for Cantabrian-Baruelian and Stephanian B-C coals reveals that they were formed in a swamp environment with facies rich in precursors of vitrinite and variable mineral matter inputs.

\subsection{Coal rank. Main causes of the coal rank distribution of Carboniferous coals}

The map in Fig. 8 shows the general coal rank distribution of the coalfields of the Cantabrian Mountains on the basis of vitrinite reflectance values (Table 3). This table also shows the classification of the Stephanian B-C, Cantabrian-Barruelian and Westphalian coals according to the ISO $11760,(2005)$. In general, data compiled from direct reflectance determinations were used for the investigated coalfields. However, in the case of coals with relatively low ash content for which vitrinite reflectance data were not available, the corresponding reflectance values were tentatively approached from the correlation established between the volatile matter contents (daf basis) with the measured vitrinite random reflectances (\%) shown in Fig. 9. This figure was composed using values of these two coal rank parameters directly measured from a total of 524 coal samples of the Westphalian (some data are reported in Piedad-Sánchez et al., 2004b),
Table 2

Ranges of ash contents for coals from the Stephanian B-C, Cantabrian-Barruelian and Westphalian coalfields in the North of Spain and ash class categories according to the ISO 11760 (2005)

\begin{tabular}{|c|c|c|}
\hline & $\begin{array}{l}\text { Ash content range } \\
\text { (wt.\%, db) }\end{array}$ & Ash class categories (ISO)* \\
\hline \multicolumn{3}{|l|}{ Stephanian B-C coalfields } \\
\hline Arnao & $6.6-10.0$ & Low ash \\
\hline Tineo & $7.0-40.0$ & $\begin{array}{l}\text { Low ash, medium ash, } \\
\text { moderately high ash, high ash }\end{array}$ \\
\hline Cangas & $9.7-40.0$ & $\begin{array}{l}\text { Low ash, medium ash, } \\
\text { moderately high ash, high ash }\end{array}$ \\
\hline Carballo & $35.0-40.0$ & High ash \\
\hline Rengos & $6.5-35.0$ & $\begin{array}{l}\text { Low ash, medium ash, } \\
\text { moderately high ash, high ash }\end{array}$ \\
\hline Villablino & $13.4-48.0$ & $\begin{array}{l}\text { Medium ash, moderately } \\
\text { high ash, high ash }\end{array}$ \\
\hline Tormaleo, Ibias & $13.3-23.5$ & $\begin{array}{l}\text { Medium ash, moderately } \\
\text { high ash, high ash }\end{array}$ \\
\hline El Bierzo & $7.0-48.0$ & $\begin{array}{l}\text { Low ash, medium ash, } \\
\text { moderately high ash, high ash }\end{array}$ \\
\hline Ventana & $30.0-38.0$ & High ash \\
\hline La Magadalena & $10.0-30.0$ & Medium ash, moderately high ash \\
\hline Ciñera-Matallana & $24.0-46.0$ & Moderately high ash, high ash \\
\hline Canseco - Salamón** & $5.0-32.4$ & $\begin{array}{l}\text { Low ash, medium ash, } \\
\text { moderately high ash, high ash }\end{array}$ \\
\hline Sabero & $8.1-49.0$ & $\begin{array}{l}\text { Low ash, medium ash, } \\
\text { moderately high ash, high ash }\end{array}$ \\
\hline \multicolumn{3}{|c|}{ Cantabrian-Barruelian coalfields } \\
\hline Barruelo & $10.0-50.0$ & $\begin{array}{l}\text { Medium ash, moderately } \\
\text { high ash, high ash }\end{array}$ \\
\hline Redondo & $12.9-32.4$ & $\begin{array}{l}\text { Medium ash, moderately } \\
\text { high ash, high ash }\end{array}$ \\
\hline Castillería** & $14.5-48.5$ & $\begin{array}{l}\text { Medium ash, moderately } \\
\text { high ash, high ash }\end{array}$ \\
\hline La Pernía** & $14.5-48.5$ & $\begin{array}{l}\text { Medium ash, moderately } \\
\text { high ash, high ash }\end{array}$ \\
\hline Valderrueda & $7.6-45.0$ & $\begin{array}{l}\text { Low ash, medium ash, } \\
\text { moderately high ash, high ash }\end{array}$ \\
\hline Guardo-Cervera & $7.5-50.0$ & $\begin{array}{l}\text { Low ash, medium ash, } \\
\text { moderately high ash, high ash }\end{array}$ \\
\hline Gamonedo-Cabrales** & $17.4-50.0$ & $\begin{array}{l}\text { Medium ash, moderately } \\
\text { high ash, high ash }\end{array}$ \\
\hline Sebarga - Fontecha** & $36.0-49.2$ & High ash \\
\hline \multicolumn{3}{|l|}{ Westphalian coalfields } \\
\hline La Camocha & $6.1-33.9$ & $\begin{array}{l}\text { Low ash, medium ash, } \\
\text { moderately high ash, high ash }\end{array}$ \\
\hline Viñón-Libardón & $5.5-18.6$ & $\begin{array}{l}\text { Medium ash, moderately } \\
\text { high ash, high ash }\end{array}$ \\
\hline Beleño** & $21.6-47.8$ & Moderately high ash, high ash \\
\hline La Marea-Coballes** & $2.0-38.9$ & $\begin{array}{l}\text { Very low ash, low ash, medium ash, } \\
\text { moderately high ash, high ash }\end{array}$ \\
\hline Central Asturian & $2.2-49.5$ & $\begin{array}{l}\text { Very low ash, low ash, medium ash, } \\
\text { moderately high ash, high ash }\end{array}$ \\
\hline Quirós & $1.4-33.2$ & $\begin{array}{l}\text { Very low ash, low ash, medium ash, } \\
\text { moderately high ash, high ash }\end{array}$ \\
\hline San Emiliano** & $10.3-49.8$ & $\begin{array}{l}\text { Medium ash, moderately } \\
\text { high ash, high ash }\end{array}$ \\
\hline Teverga & $4.2-46.6$ & $\begin{array}{l}\text { Very low ash, low ash, medium ash, } \\
\text { moderately high ash, high ash }\end{array}$ \\
\hline
\end{tabular}

*For limits of ash class categories see ISO 11760 (2005).

**Carbonaceous shales (ash content $>50 \mathrm{wt} . \%, \mathrm{db}$ ) are very common. Refer to Fig. 1 for locations.

Cantabrian-Barruelian and Stephanian ages distributed all over the investigated area. They cover a wide rank range, from bituminous $C$ coals to anthracite A coals.

The Westphalian coal seams display a coal rank that varies from bituminous D coals $(\mathrm{Rr} \geq 0.5 \%)$ to anthracite $\mathrm{A}(\mathrm{Rr}<6.0 \%)$ coal rank (Fig. 8 and Table 3 ). In general, most of the less mature Westphalian coals are in the sub-category of bituminous $C$ coals $(0.6 \% \leq R r<1.0 \%)$. Only a few coals with reflectance values between 0.5 and $0.6 \%$ (bituminous D subcategory) were found with a local character. These coal samples are from 


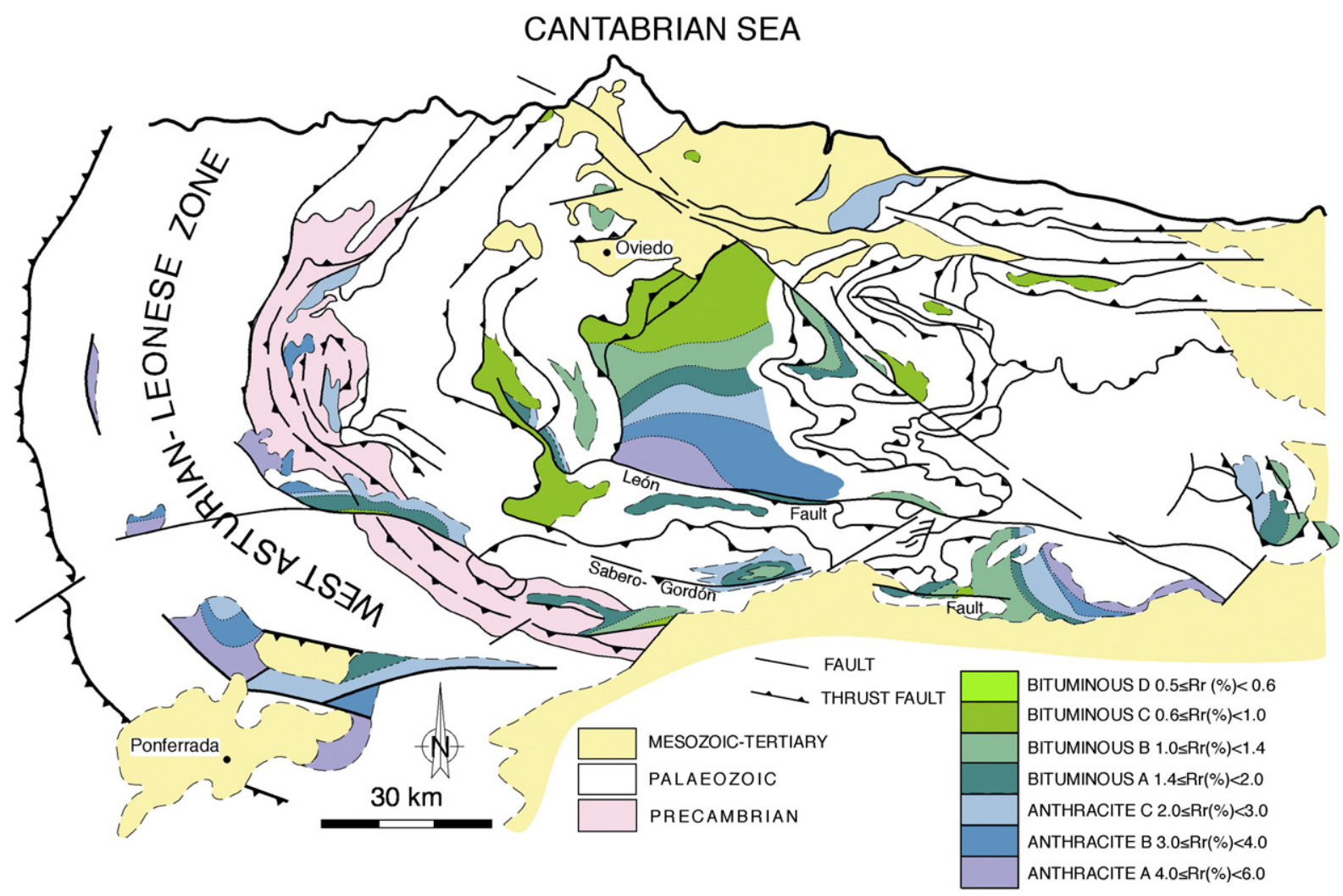

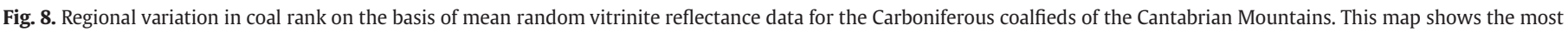
representative coal rank for each coalfield. Refer to Table 3 for a more detailed information on the different classes of coals in these coalfields.

two coal beds located in the upper part of the productive Westphalian series in the Central Asturian coalfield. In this coalfield the coal rank quickly increases from north to south (Pajares area, close to the León Fault, Fig. 1) as reported by Colmenero and Prado (1993) and Piedad-Sánchez et al. (2004a,b). The latter attributed this increase in coal rank trend to a significant thermal flux (in addition to the geothermal gradient), probably in response to a deep intrusive granitoid of large size, that might explain the presence of these high-rank coals towards the south of the Central Asturian coalfield and surrounding areas. New vitrinite reflectance data $(\sim 5.0 \% \mathrm{Rr})$ of coal seams from this area that are higher than those reported in Piedad-Sánchez et al. (2004b) are now included in this work (Table 3). These values have confirmed that the most mature Westphalian coals (anthracite A coals, $4.0 \% \leq \mathrm{Rr}<6.0 \%$ ) occur towards the south part of the region, particularly in the Pajares area (close to the León Fault) of the Central Asturian coalfield (Figs. 1, 8 and Table 3). These high reflectance values are inside the limits described by Teichmüller et al. (1979) for anchimetamorphism, although according to Merriman and Frey (1999) they fit better in the epizone. Although the values reported by Teichmüller et al. (1979) (in Stach et al., 1982, page 85) are approximate and they have been a subject of debate in the literature, they coincide very well with the data available from the CAI (Conodont Alteration Index) and Illite Crystallinity indices obtained in the same Westphalian area by García-López et al. (1999, 2007). The north to south increase in coal rank for the Westphalian coals in this sector and the vitrinite reflectance data on coals from the Pajares area, suggests that the León fault (see Fig. 1) and the processes associated with this large structure may have been the source of a supplementary heat flow that caused a strong coalification of the coal seams close to this fault. Moreover, the heat flow associated to this fault provoked an aureola of decreasing coal rank towards the north area (Fig. 8 and Table 3).

Other Westphalian coalfields, such as Teverga, San Emiliano, Quirós, La Marea-Coballes or Viñón-Libardón, show a variable coal rank distribution (Table 3, Figs. 1 and 8). In the case of Viñon-Libardón, the high rank of its coals (anthracite C, $2.0 \% \leq \mathrm{Rr}<3.0 \%$ ) seems to be related to the Infiesto basic-intermediate intrusions (Fig. 10). Coals from the Quirós, Teverga and La Marea-Coballes coalfields (Figs. 1, 8 and Table 3 ) are less mature (bituminous C-A coals, $0.6 \% \leq R r<2.0 \%$, Table 3 ) which agrees with their location in a diagenetic metamorphic zone, the latter being related to burial metamorphism, as described by García-Lopez et al. (2007).

The coal rank distribution in the Cantabrian-Barruelian coalfields shows a rough arch geometry (Figs 1, 8 and Table 3) around the Paleozoic of the Pisuerga-Carrión Unit, where there is a considerable number of small late-Variscan intrusions (Fig. 10) of a wide compositional variety, ranging from gabbros to granites (Corretgé and Suárez, 1990). The rank of the coal seams in these coalfields (Table 3, Figs. 8 and 11) increases to anthracite (high rank coals, $\mathrm{Rr}>2.0 \%$ ) towards the inner areas of this arch (Guardo-Cervera, sector of the Guardo coalfield, and La Pernía coalfield), whereas it decreases to bituminous B coals in the outer areas (OcejoTejerina sector of the Guardo coalfield, and Redondo and Barruelo coalfields, see Table 3 and Figs. 8 and 11). The most evolved coal seams (with reflectance values between $4.0 \%$ and $6.0 \%$ ) are found in mines from the Guardo Basin.

The coal rank of the Stephanian B-C coals (Table 3 and Figs. 1, 8) spans from bituminous C to anthracite A coals (from $0.6 \%$ to $6.0 \%$ vitrinite reflectance). The rank increases from the coalfields located in the east of the Cantabrian Zone (Canseco-Salamón and Sabero coalfields, Table 3, Figs. 8 and 12) towards the coalfields located in the Narcea Antiform and West Asturian-Leonese domains (Fig. 2). The most thermally mature coals (anthracite A coals, $4.0 \% \leq \mathrm{Rr}<6.0 \%$ ) are located in the Torre-Bembibre sector of the El Bierzo coalfield (Table 3, Figs. 8 and 13).

The data obtained from the vitrinite reflectance rank parameter (Table 3 ) and the regional coal rank distribution of the Upper Carboniferous coalfields (Fig. 8) suggest that the Cantabrian-Barruelian and Stephanian B-C coals developed a higher rank than the 
Table 3

Ranges of mean random vitrinite reflectance for the Stephanian B-C, CantabrianBarruelian and Westphalian coalfields in the North of Spain and classification of their coals according to the ISO 11760 (2005)

\begin{tabular}{|c|c|c|c|}
\hline & \multicolumn{3}{|l|}{ Classes of coals } \\
\hline & $\operatorname{Rr}(\%)$, range & Sub-caterogies (ISO)* & Category (ISO)* \\
\hline \multicolumn{4}{|c|}{ Stephanian B-C coalfields } \\
\hline Arnao & $0.90-0.95$ & Bituminous C & Medium coal-rank \\
\hline Tineo & $2.48-2.84,4.53$ & Anthracite C, A & High coal-rank \\
\hline Cangas & $3.00-3.60$ & Anthracite B & High coal-rank \\
\hline Carballo & $2.30-2.40$ & Anthracite C & High coal-rank \\
\hline Rengos & $3.00-5.22$ & Anthracite B, A & High coal-rank \\
\hline Villablino & $1.12-4.24$ & $\begin{array}{l}\text { Bituminous B, A, } \\
\text { Anthracite C, B, A }\end{array}$ & $\begin{array}{l}\text { Medium coal-rank- } \\
\text { high coal-rank }\end{array}$ \\
\hline Tormaleo, Ibias & $3.80-5.85$ & Anthracite B, A & High coal-rank \\
\hline El Bierzo & $1.87-5.25$ & $\begin{array}{l}\text { Bituminous A, } \\
\text { Anthracite C, B, A }\end{array}$ & $\begin{array}{l}\text { Medium coal-rank- } \\
\text { high coal-rank }\end{array}$ \\
\hline Ventana & $1.50-2.57$ & $\begin{array}{l}\text { Bituminous A, } \\
\text { Anthracite } \mathrm{C}\end{array}$ & $\begin{array}{l}\text { Medium coal-rank- } \\
\text { high coal-rank }\end{array}$ \\
\hline La Magadalena & $1.20-1.92$ & Bituminous B, A & Medium coal-rank \\
\hline Ciñera-Matallana & $0.76-4.03$ & $\begin{array}{l}\text { Bituminous C, B, A, } \\
\text { Anthracite C, B, A }\end{array}$ & $\begin{array}{l}\text { Medium coal-rank- } \\
\text { high coal-rank }\end{array}$ \\
\hline Canseco - Salamón & $0.81-2.00$ & Bituminous $\mathrm{C}, \mathrm{B}, \mathrm{A}$ & Medium coal-rank \\
\hline Sabero & $0.92-1.50$ & Bituminous C, B, A & Medium coal-rank \\
\hline \multicolumn{4}{|c|}{ Cantabrian-Barruelian coalfields } \\
\hline Barruelo & $1.13-1.50$ & Bituminous B, A & Medium coal-rank \\
\hline Redondo & $0.74-2.28$ & $\begin{array}{l}\text { Bituminous C, B, A, } \\
\text { Anthracite C }\end{array}$ & $\begin{array}{l}\text { Medium coal-rank- } \\
\text { high coal-rank }\end{array}$ \\
\hline Castillería & $1.08-1.33$ & Bituminous B & Medium coal-rank \\
\hline La Pernía & $1.25-3.00$ & $\begin{array}{l}\text { Bituminous B, A, } \\
\text { Anthracite C, }\end{array}$ & $\begin{array}{l}\text { Medium coal-rank- } \\
\text { high coal-rank }\end{array}$ \\
\hline Valderrueda & $1.03-3.82$ & $\begin{array}{l}\text { Bituminous B, A, } \\
\text { Anthracite C, B }\end{array}$ & $\begin{array}{l}\text { Medium coal-rank- } \\
\text { high coal-rank }\end{array}$ \\
\hline Guardo-Cervera & $1.12-5.64$ & $\begin{array}{l}\text { Bituminous B, A, } \\
\text { Anthracite C, B, A }\end{array}$ & $\begin{array}{l}\text { Medium coal-rank- } \\
\text { high coal-rank }\end{array}$ \\
\hline Gamonedo-Cabrales & $0.80-0.90$ & Bituminous C & Medium coal-rank \\
\hline Sebarga-Fontecha & $0.73-0.76$ & Bituminous C & Medium coal-rank \\
\hline \multicolumn{4}{|l|}{ Westphalian coalfields } \\
\hline La Camocha & $0.75-0.88$ & Bituminous C & Medium coal-rank \\
\hline Viñón-Libardón & $2.22-2.48$ & Anthracite C & High coal-rank \\
\hline Beleño & $0.80-1.23$ & Bituminous C, B & Medium coal-rank \\
\hline La Marea-Coballes & $0.64-2.00$ & Bituminous C, B, A & Medium coal-rank \\
\hline Central Asturian & $0.51-5.63$ & $\begin{array}{l}\text { Bituminous D, C, B, A, } \\
\text { Anthracite C, B, A }\end{array}$ & $\begin{array}{l}\text { Medium coal-rank- } \\
\text { high coal-rank }\end{array}$ \\
\hline Quirós & $0.87-1.90$ & Bituminous C, B, A & Medium coal-rank \\
\hline San Emiliano & $0.80-1.53$ & Bituminous C, B, A & Medium coal-rank \\
\hline Teverga & $0.70-0.88$ & Bituminous C & Medium coal-rank \\
\hline
\end{tabular}

Some vitrinite reflectance data for the Central Asturian (Westphalian age) and CiñeraMatallana (Stephanian age) coalfields are from Piedad-Sánchez et al. (2004b) and Frings et al. (2004) respectively. Refer to Fig. 1 for locations.

$\mathrm{Rr}$ : mean random vitrinite reflectance.

*For vitrinite reflectance limits of rank sub-categories and rank categories see ISO 11760 (2005).

Westphalian coals despite the high rank found for the coal seams (Westphalian) in the south of the Central Asturian coalfield (Pajares area close to the León Fault, Figs. 1 and 8). The Cantabrian-Barruelian and Stephanian B-C coal basins with the highest coal rank are located in areas affected by the late-Variscan metamorphism-plutonism (Fig. 10) and in some cases close to hydrothermal gold mineralisations. The high thermal fluxes associated with these magmatic events seem to have provided the necessary temperature to accelerate the evolution of these coal seams up to anthracite coal rank ( $\mathrm{Rr}>2.0 \%)$.

The metamorphic areas in the NW Iberian Variscan Massif form elongated belts parallel to the main structural trends that define the arcuate shape of the foldbelt. Variscan granitoid plutonism is mostly associated with these belts (Martínez et al., 1988; Suárez et al., 1990; Fernández-Suárez et al., 2000). The Novellana-Pola de AllandeDegaña and Boal-Ancares (Fig. 10) are the most external metamorphic belts in the NW Iberian Variscan Massif. As can be seen from the Fig. 10, they form elongated belts parallel to the main structural trends that are located in the eastern part of the West Asturian-Leonese Zone and westernmost part of the Cantabrian Zone, the areas where most of the Stephanian B-C coalfields are located.

In the Novellana-Pola de Allande-Degaña belt (Fig. 10), where the Cangas, Tineo, Carballo, Rengos, Villablino and La Magdalena coalfields are situated, signs of late-Variscan igneous activity are widespread although of little volumetric importance at the present level of exposure in the outcrops. The rest of the intrusive rocks are small (metric to hectometric) dykes or plugs ranging in composition from gabbroic to granitic (Suárez and Corretgé, 1987; Gutiérrez Alonso, 1992 and references therein). All these rocks have been emplaced in very shallow crustal levels (epizonal intrusions). Metamorphism in this belt is characterized by associations with post-kinematic biotite, clorite and muscovite in metapelitic rocks. Locally, associations with andalusite \pm cordierite have developed in the vicinity of the intrusions. The northwards increase in coal rank (Table 3, Figs. 8 and 13) along the NovellanaPola de Allande-Degaña belt (Colmenero and Prado, 1993, and this work) from bituminous B-A coals (La Magdalena coalfield), through bituminous A, anthracite C-B and anthracite A coals (Villablino coalfield, and Carballo, Tineo, Cangas and Rengos, coalfields) is consistent with the greater abundance of igneous rocks in the area occupied by most mature coals (anthracitic, Figs. 10 and 13). The southwards increase in coal rank from anthracites $C$ to anthracites $A$ in the El Bierzo coalfield (Fig. 13) may reflect the increasing proximity to the thermal axis of the Boal-Los Ancares belt (Fig. 10).

The Boal-Los Ancares belt is situated to the west (Fig. 10) of the Novellana-Pola de Allande-Degaña belt. The largest Stephanian B-C coalfield (El Bierzo) is located at its southeastern end (Figs. 10 and 13). This belt is characterised by the occurrence of small epizonal intrusions along its thermal axis which is composed of mantle-derived gabbroic and I-type granodioritic rocks (Corretgé et al., 1990) and by peraluminous crustally derived two-mica monzogranites and leucogranites (Fernández-Suárez, 1994). These intrusions were emplaced after the main Variscan deformation phases and do not reflect any subsequent deformation. Late-Variscan metamorphism in the Boal-Los Ancares belt is essentially post-kinematic and characterised by associations with biotite, andalusite and cordierite (Fernández-Suárez, 1994). Lowpressure metamorphism in the Boal-Los Ancares belt was produced as a consequence of the intrusion of voluminous amounts of granitoid magma in the upper crust (Fernández-Suárez, 1994), of which outcropping plutons represent a relatively small proportion.

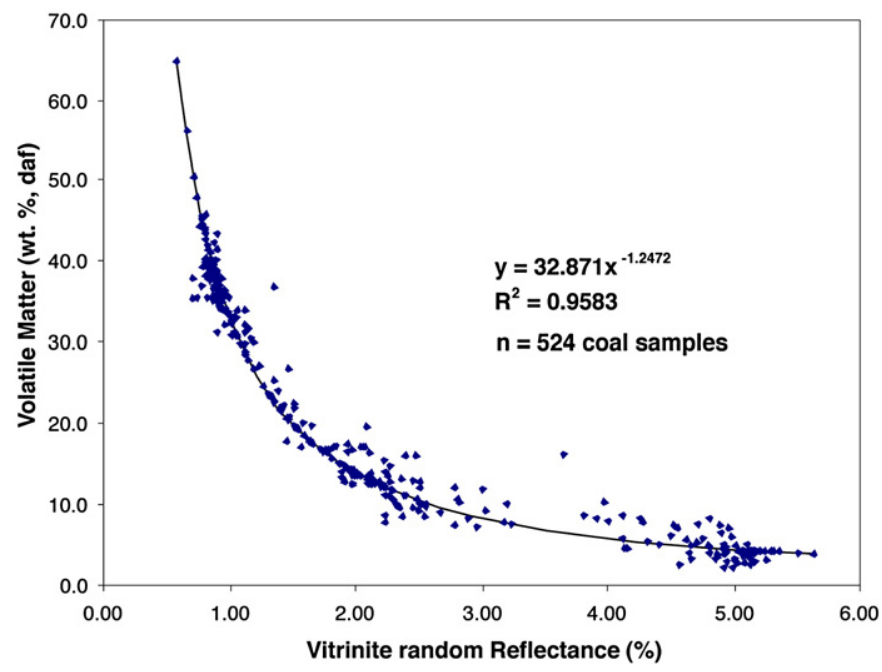

Fig. 9. Relationship between the vitrinite random reflectance (measured) and volatile matter content (determined) for a total of 524 Carboniferous coals. Some analytical data of the Westphalian coals from the North part of the Central Asturian coalfield were taken from Piedad-Sánchez et al. (2004b).(daf: dry ash free basis). 


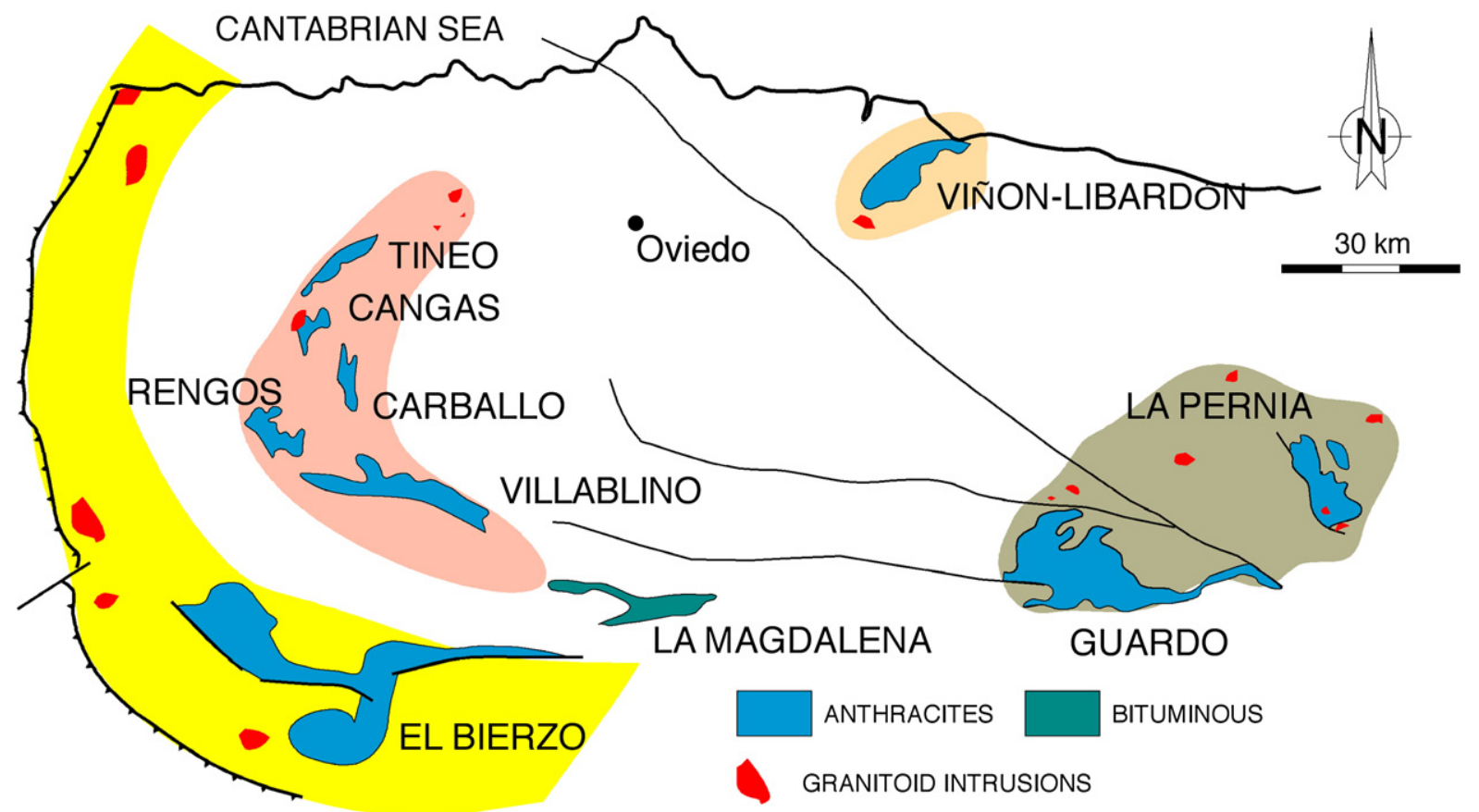

BOAL-ANCARES LOW-PRESSURE HIGH-TEMPERATURE METAMORPHIC BELT

INFIESTO BASIC-INTERMEDIATE INTRUSIONS

NOVELLANA-POLA DE ALLANDE-DEGAÑA

PALENTIAN ZONE GRANITOIDS

Fig. 10. Relationship between coal rank and late-Variscan thermal events.

The age of late-Variscan plutonism and associated low-Pressure metamorphism lies between 305 and $290 \mathrm{Ma}$, with a peak at 290295 Ma (early Permian) (Valverde-Vaquero et al., 1999; FernándezSuárez et al., 2000). A recent study by Gutierrez-Alonso et al. (2003) has suggested a possible link between the late-Variscan thermal rise and concomitant magmatism and regional scale low-Pressure,
high-Temperature metamorphism with orocline-driven lithospheric delamination and mantle replacement (asthenospheric upwelling) under the core of the Ibero-Armorican Arc. These data indicate that late-Variscan thermal events took place after the Stephanian times, and therefore they may have acted as the main supplementary heat source in the coalification of most of the cited coal-successions.

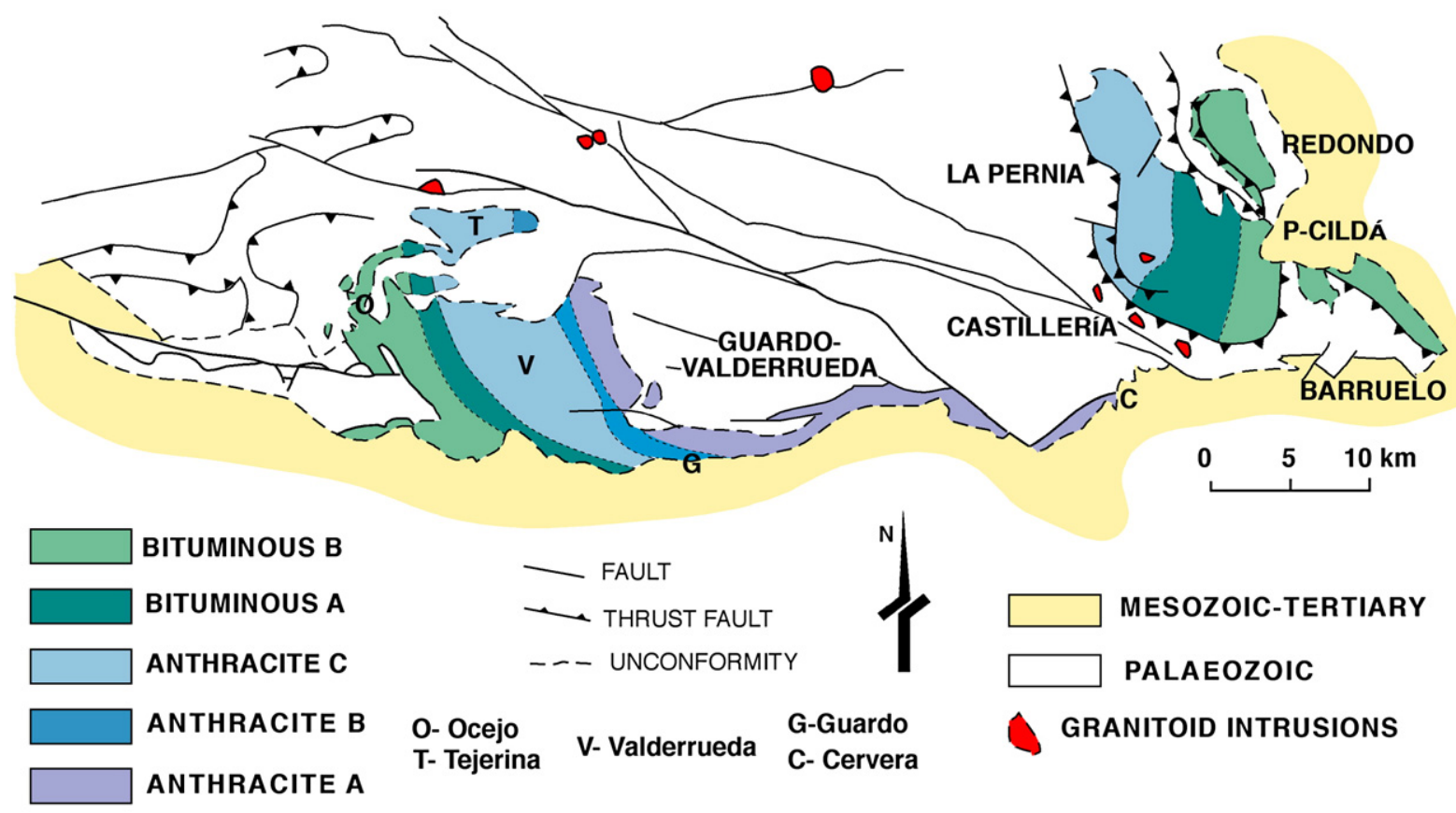

Fig. 11. Map showing the regional rank distribution (on the basis of vitrinite reflectance data) of the Cantabrian-Barruelian coalfields. 


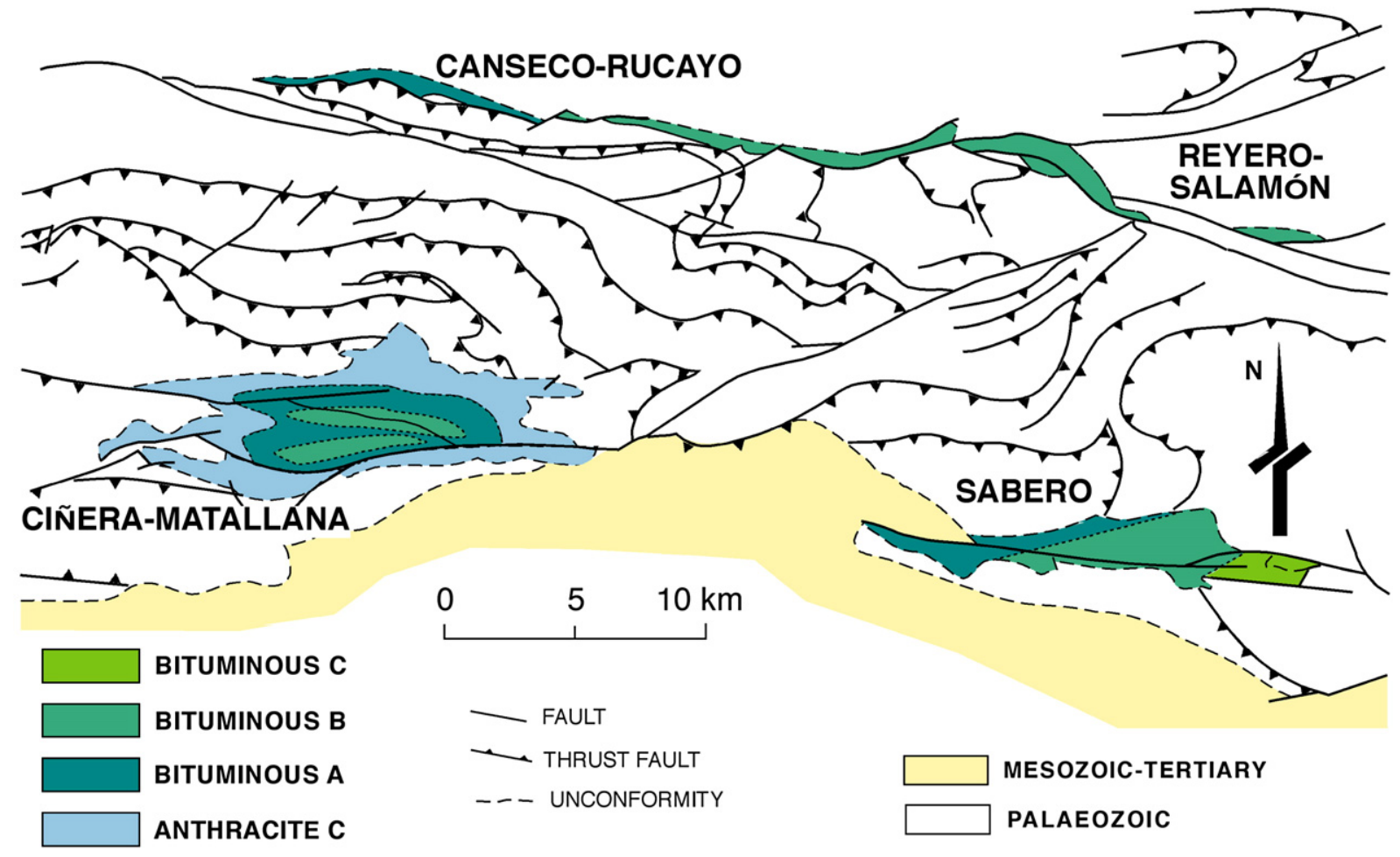

Fig. 12. Detailed map showing the rank distribution (on the basis of vitrinite reflectance data) of the Stephanian B-C coalfields of the Cantabrian Mountains.

The temperature range of late-Variscan metamorphism is approximately $400-450{ }^{\circ} \mathrm{C}$ to $600{ }^{\circ} \mathrm{C}$ which is consistent with mineral assemblages, biotite-garnet geothermometry (Fernández-Suárez, 1994) and the location of experimentally calibrated reactions in the Pressure-Temperature space.

The above described is supported by the high coal rank and the specific structures found in some coals of Cantabrian-Barruelian and Stephanian B-C age (Table 3 and Fig. 8) under microscopic observation (Fig. 14). In coals of the highest rank (anthracite A coals, $4.0 \% \leq \operatorname{Rr}<6.0 \%)$ thermally altered particles and the development of micro-structures typical of coals affected by high temperatures were observed. The organic fraction of these more mature coals is always strongly anisotropic, at times showing the various types of optical textures, similar to those reported for some Russian and Chinese anthracites by Duber et al. (2000). Moreover, the development of porosity (mainly due to the devolatilization process) of very small size over their entire surface of the organic particles is common (Fig. 14). This is a frequent feature observed in coals from El Bierzo (Stephanian B-C age) and Guardo (Cantabrian-Barruelian) coalfields (Fig. 1). Moreover, coal particles ranging from partially carbonized to natural coke are also very frequent in the most evolved coals of these areas (Fig. 14). Natural coke is also common in La Rasa Mine from the Tineo coalfield in the Narcea Antiform (Figs. 1, 10 and 13) and the main features of this natural coke were already described by Kwiecinska et al. (1995). In some specific coal seams as it is the case of coals from the Besande Mine (North of the Valderrueda and Guardo coalfields, see for location Figs. 1 and 11) newly-formed constituents such as relatively large nodules of pyrolitic carbon (Fig. 14) were also found (Llorens et al., 2006b). All these characteristics confirm that these coals were affected by high temperatures probably corresponding to a second and additional thermal gradient (different from the normal geothermal gradient) such as that provided by magmatic intrusions.

In view of the location of these coalfields in the context of the area under study and the strong tectonism affecting the entire region (Figs. 1 and 2), the effect that local faults with hot fluid circulation on the coals could be another supplementary factor contributing to the increase in the coal rank of the Cantabrian-Barruelian and Stephanian B-C coals.

Stephanian B-C coalfields which are not associated with these two described metamorphic belts (the Sabero, Canseco-Salamón, CiñeraMatallana, and Arnao coalfields, Figs. 1, 8, 12 and Table 3) globally contain lower rank coals. The Ciñera-Matallana coalfield, that also shows the highest coal rank of these basins (anthracite C-A coals, $2.0 \% \leq \mathrm{Rr} \sim 4.0 \%$ ), is proximal to doleritic intrusions (Méndez-Cecilia, 1985; Colmenero and Prado, 1993; Frings et al., 2004).

The arguments presented above suggest that the CantabrianBarruelian and Stephanian B-C coals underwent a different thermal evolution to that of the Westphalian coal seams. Although the geothermal gradient could in general affect all the Upper Carboniferous coals, for the unconformably structured Cantabrian-Barruelian and Stephanian B-C coal basins a second heat flow of a regional nature may have occurred. This heat flow may have been induced by the lateVariscan magmatism, an event that seems to have been the main factor contributing to the strong coalification of coals. This would explain the high rank reached by most of the Cantabrian-Barruelian and Stephanian B-C basins (Table 3, Figs. 8 and 10) and the presence in their coals of some specific micro-structures as those shown in Fig. 14.

The role of heat transfer by fluids and hydrothermal activity of the coals in the studied area is considered to be a very important factor in the process of coalification (Colmenero and Prado, 1993). Compelling evidence of the importance of fluids during the late-Variscan thermal events has also been highlighted by Arias et al. (1993), FernándezSuárez (1994), García-Lopez et al. (1999, 2007), and Gasparrini et al. (2003). The thermal effect of the intrusion of granitoids and basic rocks in very shallow levels of the crust may have been enhanced by the upward migration of high-Temperature fluids of magmatic origin. These fluids may have been channelled through deep faults related to the onset of the extensional collapse of the orogenic belt. Considering that plutons were emplaced at $P<\approx 2$ kbar, the effect of fluids may have restricted the thermal influence of the intrusions to very shallow 


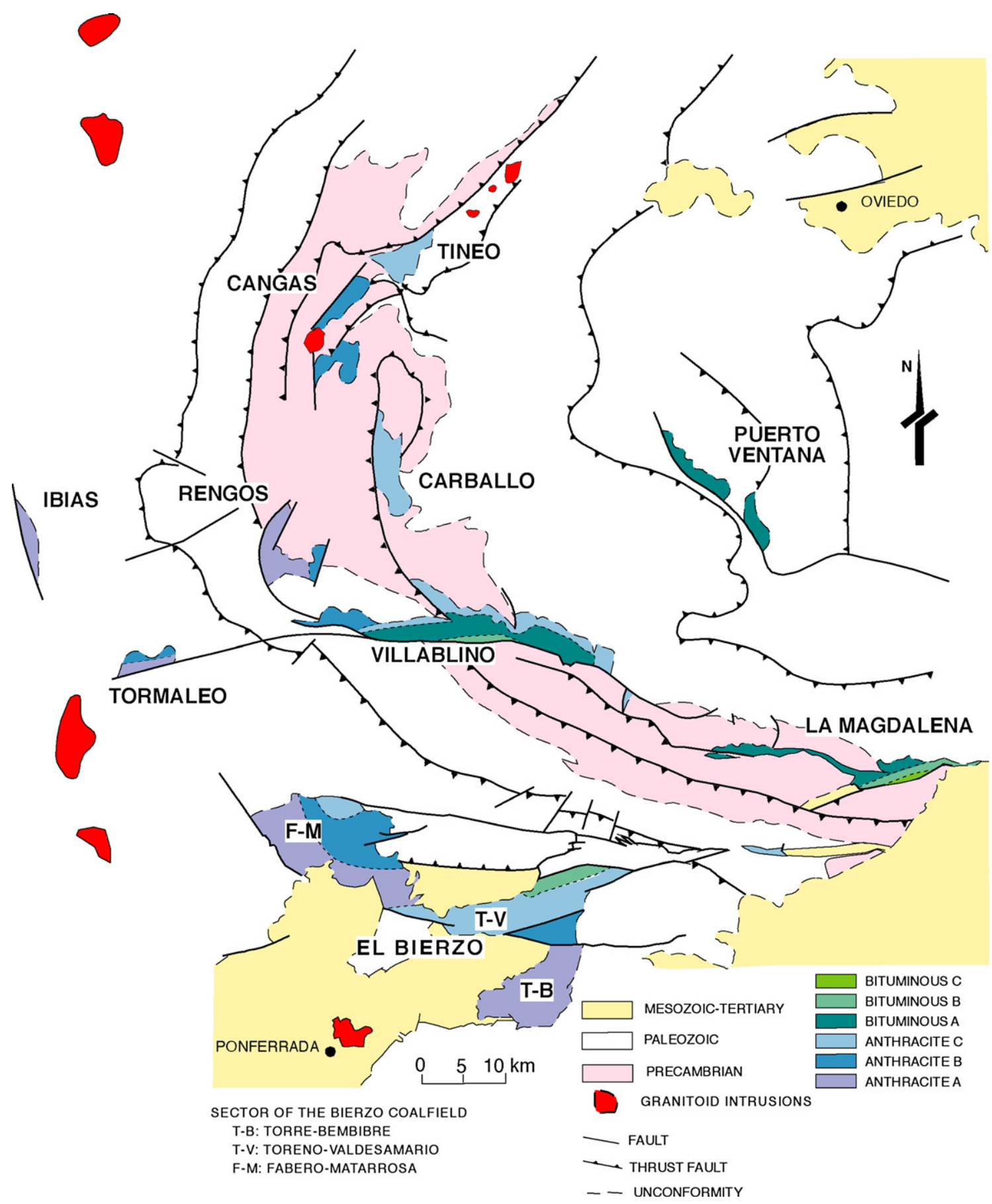

Fig. 13. Detailed map showing the rank distribution (on the basis of vitrinite reflectance data) of the westernmost Stephanian B-C coalfields of the Cantabrian Mountains.

depths (less than $3 \mathrm{~km}$ ) in a sufficient volume to provide the necessary temperature so as to accelerate the evolution of the coals to anthracite coal rank.

\section{Conclusions}

From this work the following main conclusions can be drawn:

1. - The Carboniferous coal basins in the Cantabrian Mountains (Spain) may be subdivided into three groups according to their age, origin and tectonosedimentary evolution. The coal basins of the first group are of Namurian-Westphalian age and are located in the central area of the Cantabrian Zone. They correspond to a foreland basin originated during the sinorogenis phases of the Variscan deformation that affected the entire region. The second group of coal-bearing successions are of Cantabrian-Barruelian age. They are located in the southeastern part of the Cantabrian Zone and their deposits corresponded to small foreland basins that formed during the final compressive phases of the Variscan orogeny. The third group of coal basins are of Stephanian B and C age. They appear widespread over the entire region and are represented by small intramontane basins that developed during the postorogenic phases on the Variscan range.

2. - The rank of the coals in these Carboniferous basins varies from bituminous $\mathrm{D}$ to anthracite $\mathrm{A}(0.5 \% \leq \mathrm{Rr}<6.0 \%)$. Coal contains from high to very high vitrinite maceral percentages and low to scarce inertinite and liptinite contents. The ash content is highly variable for the coals from the three types of basins. 

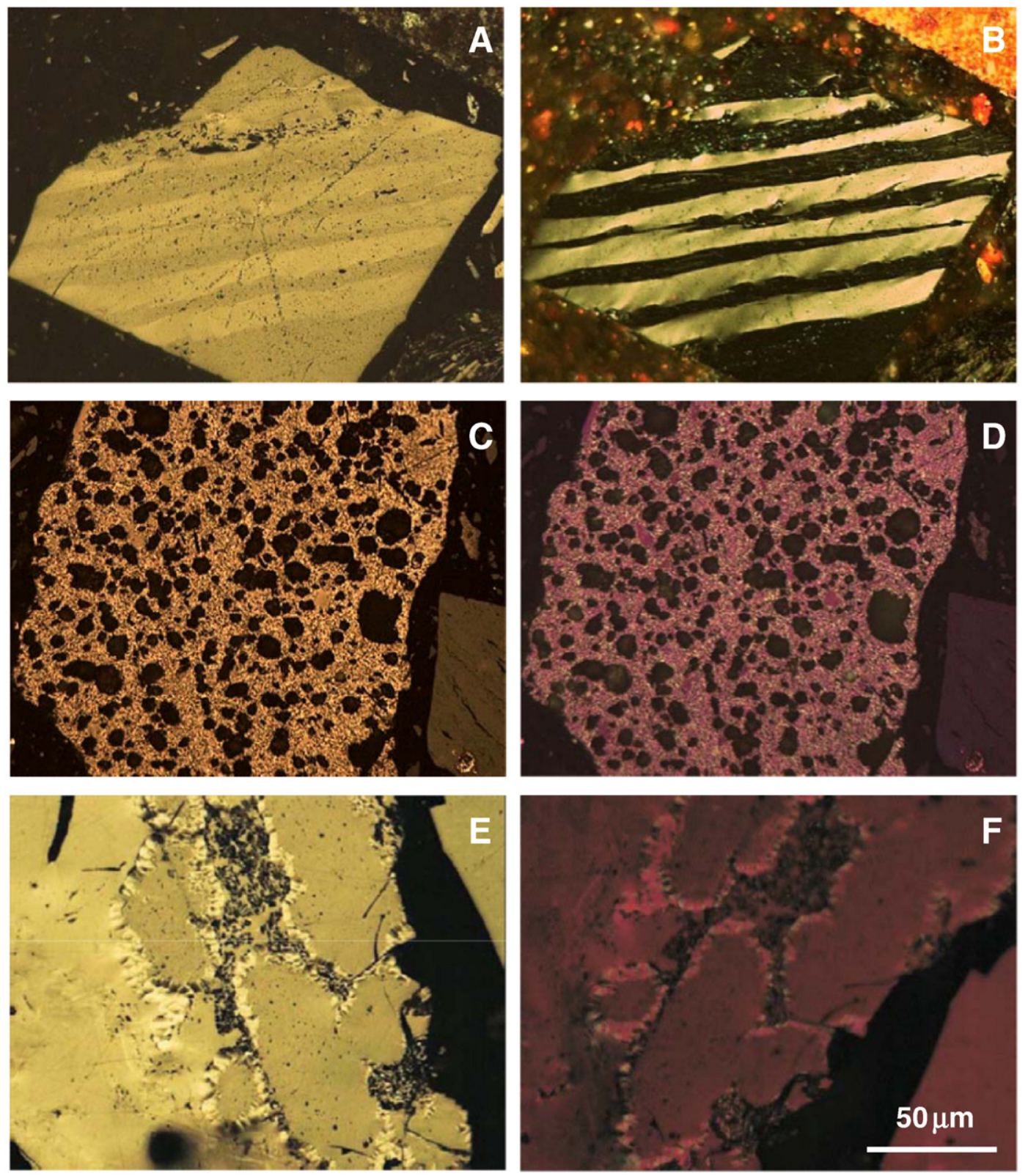

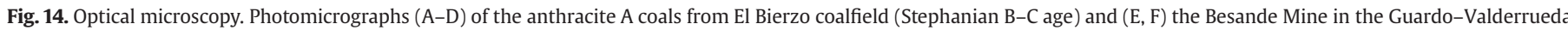

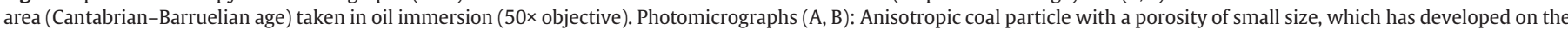

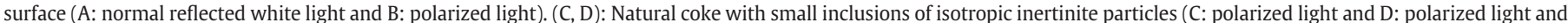
one- wave retarder plate). (E, F): Pyrolitic carbon around the coal particles. (E: normal reflected white light and F: polarized light and one-wave retarder plate).

3. - The spatial coal rank distribution suggests that, in general, the rank increases from the Westphalian coals to the CantabrianBarruelian and Stephanian B-C ones. This rank trend is thought to be because Cantabrian-Barruelian and Stephanian B-C coal basins are located in regions that had a high thermal gradient during the lower Permian age.

4. - The intrusion of granitoid bodies into the shallow crust levels facilitated the migration of hot fluids towards the surface across the deep existing faults thereby favouring the evolution of coals in the neighbouring areas. This process seems to have been the main reason for the presence of anthracite A coals $(4.0 \% \leq \mathrm{Rr}<6.0 \%)$ at the South boundary of the Central Asturian coalfield close to the León Fault.

\section{Acknowledgements}

The authors express their gratitude to the mining companies, the Spanish power plants and the INCAR (CSIC, Spain) for providing facilities and supplying essential information related to the Carboniferous coal seams. Financial support for this research was provided from Junta de Castilla y León (Proyects SA021/04 and SA005/01) and from the Spanish Ministerio de Educación y Ciencia (Proyect CGL2004-02645/BTE). J. R. Montes from the INCAR-CSIC, (Spain) is also acknowledged for his help in preparing and analysing some coal samples. Tim A. Moore and an anonymous reviewer are also acknowledged by their constructive comments and remarks.

\section{References}

Águeda, J.A., Bahamonde, J.R., Barba, F.J., Barba, P., Colmenero, J.R., Fernández, L.P., Salvador, C.I., Vera, C., 1991. Depositional environments in Westphalian coalbearing successions of the Cantabrian Mountains, northwest Spain. Bulletin de la Société Géologique de France 162/2, 325-337.

Aller, J., Álvarez-Marrón, J., Bastida, F., Bulnes, M., Heredia, N., Marcos, A., Pérez-Estaún, A Pulgar, J.A., Rodríguez-Fernández, L.R., 2004. Estructura, deformación y metamorfismo de la Zona Cantábrica. In: Vera, J.A. (Ed.), Geología de España. Soc. Geol. España-IGME, Madrid, Spain, pp. 42-49. 
Alonso, J.L., 1982. Las discordancias progresivas de la cobertera carbonífera de Ocejo de la Peña: Testigos de la reactivación de un pliegue de basamento por flexural slip (Cordillera Cantábrica). Boletín Geológico y Minero IGME 93, 214-225.

Alonso, J.L., 1985. Estructura y evolución tectonoestratigráfica del Manto del Esla (Zona Cantábrica, NW de España). Instituto Fray Bernardino de Sahugún, Diputación Provincial de León. 276 pp.

Alonso, J.L., 1989. Fold reactivaton involving angular unconformable sequences: theoretical analysis and natural examples from the Cantabrian Zone (Northwest Spain). Tectonophysics 170, 57-77.

Alonso, J.L., Pulgar, J.A., 2004. Estructura alpina de la Codillera Cantábrica: generalidades. In: Vera, J.A. (Ed.), Geología de España (332-334). Soc. Geol. España- IGME, Madrid, Spain, pp. 332-343.

Alonso, J.L., Pulgar, J.A., García-Ramos, J.C., Barba, P., 1996. Tertiary basins and alpine tectonics in the Cantabrian Mountains (NW Spain). In: Friend, P.F., Dabrio, C.J. (Eds.), Tertiary Basins of Spain. Cambridge Univ. Press, pp. 19-22.

Arias, D., Corretgé, L.G., Suárez, O., Villa, L., Cuesta, A., Fernández-Suárez, J., 1993. Gold and base metals vein mineralitation and associated silicate bodies in the Ibias area (Asturias, NW Spain). Chronique de la Recherche Miniere 513, 25-36.

Bahamonde, J.R., Nuño, C., 1991. Características geológicas del sinclinal de Santa María de Redondo (Zona Cantábrica, Palencia). Boletín del Instituto Geológico y Minero de Espana 102 (2), 219-239.

Colmenero, J.R., Prado, J.G., 1993. Coal Basins in the Cantabrian Mountains, Northwestern Spain. International Journal of Coal Geology 23, 215-229.

Colmenero, J.R., Águeda, J.A., Bahamonde, J.R., Barba, F.J., Barba, P., Fernández, L.P., Salvador, C.I., 1993. Evolución de la Cuenca de antepaís namuriense y westfaliense de la Zona Cantábrica, NW de España. C. R. XII Inter. Congr. Carboníf. Perm, Buenos Aires, vol. 2, pp. 175-190.

Colmenero, J.R., Bahamonde, J.R., Barba, P., 1996. Las facies aluviales asociadas a los depósitos de carbón en las cuencas estefanienses de León (borde sur de la Cordillera Cantábrica). Cuadernos de Geología Ibérica 21, 71-92.

Colmenero, J.R., Fernández, L.P., Moreno, C., Bahamonde, J.R., Barba, P., Heredia, N. González, F., 2002. Carboniferous. In: Gibbons, W., Moreno, M.T. (Eds.), The Geology of Spain, Geol. Soc. London, pp. 93-116.

Corrales, I., 1971. La sedimentación durante el Estefaniense B-C en Cangas de Narcea Rengos y Villablino (NW de España). Trabajos de Geología 3, 69-73.

Corretgé, L.G., Suárez, O., 1990. Igneus rock of the Cantabrian and Palentine Zones. PreMesozoic Geology of Iberia. Springer-Verlag, Berlin, Germany, pp. 72-79.

Corretgé, L.G., Suárez, O., Galán, G., 1990. West Asturian-Leonese: igneous rocks. PreMesozoic Geology of Iberia. Springer-Verlag, Berlin, Germany, pp. 115-128.

Corretgé, L.G., Suárez, O., Galán, G., Fernández-Suárez, J., 2004. Magmatismo de la Zona Asturoccidental-Leonesa. In: Vera, J.A. (Ed.), Geología de España. IGME-Soc. Geol. España, pp. 63-68.

Dallmeyer, R.D., Martínez García, E. (Eds.), 1990. Pre-Mesozoic Geology of Iberia. Springer-Verlag, Berlin, Germany. 416 pp.

Duber, S., Pusz, S., Kwiecinska, B.K., Rouzaud, J.N., 2000. On the optically biaxia character and heterogeneity of anthracites. International Journal of Coal Geology $44,227-250$.

Espina, R.G., Alonso, J.L., Pulgar, J.A., 2004. Extensión Triásica en la Cuenca VascoCantábrica. In: Vera, J.A. (Ed.), Geología de España. Soc. Geol. España- IGME, Madrid, Spain, pp. 338-339.

Fernández, L.P., 1995. El Carbonífero. In: Aramburu, C., Bastida, F. (Eds.), Geología de Asturias. Ediciones Trea, S.L., Oviedo, España, pp. 63-80.

Fernández, L.P., Águeda, J.A., Colmenero, J.R., Salvador, C.I., Barba, P., 1988. A coal-bearing fan-delta complex in the Westfalian D of the Central Coal Basin, Cantabrian Mountains, northwestern Spain: implications for the recognition of humid-type fan deltas. In: Nemec, W., Steel, R.J. (Eds.), Fan Deltas: Sedimentology and Tectonic Settings. Blackie \& Son, London, pp. 286-302.

Fernández, L.P., Bahamonde, J.R., Barba, P., Colmenero, J.R., Heredia, N., RodríguezFernández, L.R., Salvador, C.I., Sánchez de Posada, L.C., Villa, E., Merino-Tomé, O.A Motis, K., 2004. La sucesión sinorogénica de la Zona Cantábrica. In: Vera, J.A. (Ed.) Geología de España. SGE-IGME, Madrid, pp. 34-42.

Fernández García, L., Moro Gómez, C., Gómez Prieto, J.A., Ávarez del Campo, C., 1984 Revisión y síntesis geológico-minera de la cuenca carbonífera de "El Bierzo" (León) IGME, Madrid. 98 pp.

Fernández-Suárez, J., 1994. Petrología de los granitos peralumínicos y metamorfismo de la banda Boal-Los Ancares. PhD. Thesis. University of Oviedo, Spain, 418 pp.

Fernández-Suárez, J., Dunning, G.R., Jenner, G.A., Gutiérrez-Alonso, G., 2000. Variscan collisional magmatism and deformation in NW Iberia: constraints from U-Pb geochronology of granitoids. Journal of the Geological Society of London 157, 565-576.

Frings, K., Lutz, R., Wall, H., Warr, L.N., 2004. Coalification history of the Stephanian Ciñera-Matallana pull-apart basin, NW Spain: Combining anisotropy of vitrinite reflectance and thermal modelling. International journal of earth sciences (Geologische Rundschau) 93, 92-106.

García-López, S., Bastida, F., Brime, C., Aller, J., Valin, M.L., Sanz-López, J., Méndez, C.A. 1999. Los episodios metamórficos de la Zona Cantábrica y su contexto estructural. Trabajos de Geología 21, 177-187.

García-López, S., Brime, C., Valín, M.L., Sanz-López, J., Bastida, F., Aller, J., Blanco- Ferrera S., 2007. Tectonothermal evolution of a foreland fold and thrust belt: the Cantabrian Zone (Iberian Variscan belt, NW Spain). Terra Nova 19 (6), 469-475.

García-Mondejar, J., Fernández Mendiola, P.A., Agirrezabala, L.M., Aramburu, A., López Hogue, M.A, Iriarte, E. Martínez de Rituerto, S. 2004. Extensión del AptienseAlbiense en la Cuenca Vasco-Cantábrica. In: Vera, J.A. (Ed.), Geología de España. Soc. Geol. España-IGME, Madrid, Spain, pp. 340-343.

Gasparrini, M., Bakker, R.J., Bechstädt, T.h., Boni, M., 2003. Hot dolomites in a Variscan foreland belt: hydrothemal flow in the Cantabrian Zones (NW Spain). Journal of Geochemical Exploration 78-79, 5011-5507.
Gibbons, W., Moreno, T. (Eds.), 2002. The Geology of Spain. The Geological Society, London, U.K. 649 pp.

Gutiérrez Alonso, G., 1992. El Antiforme del Narcea y su relación con los mantos occidentales de la Zona Cantábrica. PhD. Thesis. University of Oviedo, Spain. 315 pp.

Gutierrez-Alonso, G., Fernández-Suárez, J., Jeffries, T.E., Jener, G.A., Tubrett, M.N., Cox, R. Jackson, S.E., 2003. Terrane accretion and dispersal in the northern Gondwana margin. An Early Paleozoic analogue of a long lived active margin. Tectonophysics $365,221-232$.

Gutiérrez-Alonso, G., Fernández-Suárez, J., Weil, A.B., 2004. Orocline triggered lithospheric delamination. In: Sussman, A.J., Weil, A.B. (Eds.), Orogenic curvature: Integrating Paleomagnetic and Structural Analyses. Geol Soc Am Spec Paper, vol. 383, pp. 121-130.

Heward, A., 1978a. Alluvial fan sequence and lacustrine sediments from the Stephanian $A$ and b (La Magdalena, Ciñera y Sabero) coalfields, northern Spain. Sedimentology 25, 451-488.

Heward, A., 1978b. Alluvian fan sequence and megasequence models: with examples from Westphalian D-Stephanian B coalfields, Northern Spain. In: Miall, A. (Ed.), Fluvial Sedimentology. Canadian Society of Petroleum Geologists. Memoir, vol. 5, pp. 669-702.

Heward, A., Reading, A.G., 1980. Deposits associated with a Hercycian continental strike-slip system, Cantabrian Mountains, Northern Spain. Special publication of the International Association of Sedimentologists 4, 105-125.

International Organization for Standardization (ISO), 1981. Hard Coal Determination of Total Moisture. ISO-589, Switzerland. 6 pp.

International Organization for Standardization (ISO), 1994a. Methods for the Petrographic Analysis of Bituminous Coal and Anthracite - Part 3: Methods Maceral Group. ISO 7404-3. Geneva, Switzerland. 4 pp.

International Organization for Standardization (ISO), 1994b. Methods for the Petrographic Analysis of Bituminous Coal and Anthracite - Part 5: Methods Determining Microscopically the Reflectance of Vitrinite. ISO 7404-5. Geneva, Switzerland. 11 pp.

International Organization for Standardization (ISO), 1997. Solid Mineral Fuels Determination of Ash. ISO-1171, Switzerland. 4 pp.

International Organization for Standardization (ISO), 1998. Determination of Volatile Matter. ISO-562, Switzerland. 7 pp.

International Organization for Standardization (ISO), 2005. Classification of coals. ISO 11760:2005(E), 1st edition, Geneva, Switzerland. 9 pp.

Iwaniw, I., 1983. The sedimentology of Lower Cantabrian basin margin deposits in NE León, Spain. In: Lemos de Sousa, M.J., Wagner, R.H. (Eds.), Papers on the Carboniferous of the Iberian Peninsula (Sedimentology, Stratigraphy, Paleontology, Tectonics and Geochemistry). Porto, Portugal: Anais da Facultade de Ciencias, Supplement, Universidade do Porto, 64 Sp Vol. , pp. 49-115.

Iwaniw, I., 1984. Lower Cantabrian basin margin deposits in NW Spain-a model for valley-fill sedimentation in a tectonically active humic climatic setting. Sedimentology 31, 91-110.

Julivert, M., 1971. Décollement tectonics in the Hercinian Cordillera of the northwest Spain. American Journal of Science 270,1-29.

Knight, J.A., 1971. The sequence and stratigraphy of the eastern and of the Sabero Coalfield (León, NW Spain). Trabajos de Geología 3, 193-229.

Knight, J.A., Iwaniw, E., Wagner, R.H., 1983. Sabero Coalfield (Post-Asturian) and Ocejo/ Tejerina areas (Post-Leonian). Carboniferous Stratigraphy of the Cantabrian Mountanins. Field trip A. E.N. Adaro de Investigaciones Mineras, pp. 72-83.

Kwiecinska, B., Muszynski, M., Vleeskens, J., Hamburg, G., 1995. Natural coke from the La Rasa Mine, Tineo, Spain. Mineralogía Polonica 26 (2), 3-14.

López-Gómez, J., Arche, A., Pérez-López, A., 2002. Permian and Triassic. In: Gibbons, W., Moreno, M.T. (Eds.), The Geology of Spain. Geol Soc, London, pp. 185-212.

Llorens, T., Colmenero, J.R., Suárez-Ruiz, I., 2006a. Modelos de abanicos aluviales en los materiales cantabrienses (Grupo Cea) del Manto del Cea. Geogaceta 40, 275-278.

Llorens, T., Suárez-Ruiz, I., Colmenero, J.R., 2006b. Petrografía de los carbones cantabrienses (Carbonífero sup) del Grupo Cea de la cuenca Guardo-Valderrueda (León-Palencia). Geogaceta 40, 279-282.

Marcos, A., 1973. Las series del Paleozoico inferior y la estructura herciniana del occidente de Asturias. Brebiora Geol. Asturica 14, 13-18.

Marcos, A., Pulgar, F.J., 1982. An approach to the tectonostratigraphic evolution of Cantabrian thrust and fold belt, Hercynian Cordillera of NW Spain. Neues Jahrbunch für Geologie und Paläontologie Abh, 163 (2), 256-260.

Martínez, F.J., Julivert, M., Sebastián, A., Arboleya, M.L., Gil-Ibarguchi, I., 1988. Structural and termal evolution of high-grade areas in the northwestern parts of the Iberian massif. American Journal of Science, 288, 969-996.

Martínez-Catalán, J.R., Arenas, R., Díaz-García, F., Abati, J., 1997. Variscan accrectionary complex of NW Iberia: Terrane correlation and succession of tectonothermal events. Geology 25, 1103-1106.

Matte, P., 2001. The Variscan collage and orogeny (480-290 Ma) and the tectonic definition of the Armorica microplate: a review. Terra Nova 13, 122-128.

Méndez-Cecilia, A. F., 1985. Estudio de la evolución de los carbones de la Cuenca CiñeraMatallana, León. Unpublished PhD Thesis, Unv. Oviedo, Spain, 269 pp.

Merriman, R.J., Frey, M., 1999. Patterns of very low-grade metamorphism in metapelitic rocks. In: Frey, M., Robinson, D. (Eds.), Low-grade metamorphism. Blackwell Science, Oxford, U.K., pp. 61-107.

Nijman, W., Savage, J.F., 1989. Persistent basement wrenching as controlling mechanism of Variscan thin-skinned thrusting and sedimentation, Cantabrian Mountains, Spain. Tectonophysics 169, 281-302

Pérez-Estaún, A., 1978. Estratigrafía y estructura de la rama Sur de la zona Asturoccidental- leonesa. Memorias IGME $92149 \mathrm{pp}$

Pérez-Estaún, A., Bastida, F., Alonso, J.L., Marquínez, J., Aller, J., Álvarez-Marrón, J., Marcos, A., Pulgar, J.A., 1988. A thin-skinned tectonics model for an arcuate fold and thrust belt: the Cantabrian Zone (Variscan Ibero-Armorican Arc). Tectonics 7 (3), 517-537. 
Piedad-Sánchez, N., 2004. Prospection des hydrocarbures par une approche intégrée de petrographie, géochimie et modélisation de la transformation de la matière organique: Analyse et reconstitution de l'histoire thermique des Bassins Caronifère Central des Asturias (Espagne) et Sabina-Piedras Negras (Cahuila, Mexique). PhD Thesis Univ. Henri Poincaré-Nancy 1, 356 pp.

Piedad-Sánchez, N., Suárez-Ruiz, I., Martinez, L., Izart, A., Elie, M., Keravis, D., 2004a. Organic petrology and geochemistry of the Carboniferous coal seams from the Central Asturian Coal Basin (NW Spain). International Journal of Coal Geology 57, 211-242.

Piedad-Sánchez, N., Izart, A., Martínez, L., Suárez-Ruiz, I., Elie, M., Menetrier, C., 2004b. Paleothermicity in the Central Coal Basin of the Cantabrian Mountains (Spain). International Journal of Coal Geology 58, 205-229.

Pujalte, V., Robles, S., García-Ramos, J.C., Hernández, J.M., 2004. El Malm-Barremiense no marinos de la Cordillera Cantábrica. In: Vera, J.A. (Ed.), Geología de España Madrid. Soc. Geol. España-IGME, Spain, pp. 288-291.

Rodríguez Fernández, L.R., 1993. Tectonosedimentary evolution of a Carboniferous foreland basin related with arcuated fold-thrust belt. The example of NE Iberian Variscan Belt. Comptes Rendus, XII Congreso Internacional del Carbonífero y Pérmico, Buenos Aires, vol. 1, pp. 435-445.

Saldaña González, M. J., 1994. Análisis estratigráfico y sedimentológico de la cuenca carbonífera de Guardo-Cervera. PhD Thesis. Universidad de Oviedo, 243 pp.

Suárez, O., Corretgé, L.G., 1987. Plutonismo y metamorfismo en las zonas Cantábrica y Asturoccidental-leonesa. In: Bea, F., Carnicero, A., Gonzalo, J.C., López-Plaza, M., Rodríguez Alonso, M.D. (Eds.), Geología de los granitoides y rocas asociadas del Macizo Hespérico. Ed. Rueda, Madrid, Spain, pp. 13-25.

Suárez, O., Corretgé, L.G., Martínez, F.J., 1990. West Asturian-Leonese Zone distribution and characteristics of the Hercynian metamorphism. In: Dallmeller, R.D., Martínez García, E. (Eds.), Pre-Mesozoic Geology of Iberia. Springer-Verlag, Berlin, pp. 129-133.

Stach, E., Mackowsky, M.-Th., Teichmüller, M., Taylor, G.H., Chandra, D., Teichmüller, R., 1982. Coal petrology, 3rd Edition. Gebrüder Borntraeger. 535 pp.

Teichmüller, M., Teichmüller, R., Weber, K., 1979. Inkohlung und Illit-Kristallinität. Vergleichende Untersuchungen im Mesozoikum und Paläozoikum von Westfalen. Fortschr. Geol. Rheinld. u. Westf., vol. 27, pp. 201-276. Krefeld.

Valverde-Vaquero, P., Cuesta, A., Gallastegui, G., Suárez, O., Corretge, L.G., Dunning, G.R., 1999. U-Pb dating of late-Variscan magmatism in the Cantabrian Zone (Northern Spain). Terra Abstracts 11, 101.
Van de Graaff, W.J.E., 1971. Facies distribution and basin configuration in the Pisuerga area before the Leonian Phase. Trabajos de Geología 3, 161-177.

Vera, J.A. (Ed.), 2004. Geología de España. Soc. Geol. España- IGME, Madrid, Spain. 484 pp. Villegas, J., 1996. Exploración e investigación de un nuevo yacimiento de carbón en la cuenca minera Ciñera-Matallana (León). PhD. Thesis. Universidad Complutense. Madrid, Spain, 417 pp.

Wagner, R.H., 1959. Sur la presence d'une nouvelle phase tectonique "leonienne" d' âge Westphalian D dans le nord-ouest de l'Espagne. Comptes rendus de l'AcadeÂmie des sciences Paris 249, 2804-2806.

Wagner, R.H., 1971. The stratigraphy and structure of the Ciñera-Matallana coalfield (prov. León, NW Spain). University of Oviedo. Trabajos de Geología 4, 385-429.

Wagner, R.H., Artieda, J.I., 1970. La cuenca minera Ciñera-Matallana. Hullera VascoLeonesa, S.A. 288 pp.

Wagner, R.H., Varker, W.J., 1972. The distribution and development of post-Leonian strata (Upper Westphalian D, Cantabrian, Stephanian A) in northern Palencia, Spain. In: Wagner, R.H. (Ed.), The Carboniferous of Northwest Spain. Part 2 (1971). Trabajos de Geología, vol. 4, pp. 533-601.

Wagner, R.H., Winkler Prins, C.F., 1985. The Cantabrian and Barruelian stratotypes: a summary of basin development and biostratigraphic information. In: Lemos de Sousa, M.J., Wagner, R.H. (Eds.), Papers on the Carboniferous of the Iberian Peninsula (Sedimentology, Stratigraphy, Paleontology, Tectonics and Geochemistry). Anais da Facultade de Ciencias, Ssupplement vol. 64 (1983). Sp. Vol. Universidade do Porto, pp. 359-410.

Weil, A.B., 2006. Kinematic of orocline tightening in the core of an arc: Paleomagnetic analysis of Ponga Unit, Cantabrian Arc, northern Spain. Tectonics 25 (3), TC3029.

Weil, A.B., Van der Voo, R., van der Pluijm, B.A., Parés, J.M., 2000. The formation of an orocline by multiphase deformation: a paleomagnetic investigation of the Cantabrian-Asturian Arc (Northern Spain). Journal of Structural Biology 22 735-756.

Weil, A.B., Van der Voo, R., van der Pluijm, B.A., 2001. Oroclinal bending and evidence against the Pangea megashear: the Cantabria-Asturias arc (northern Spain) Geology 29, 991-994. 